\title{
STABILIZATION OF ROCKY FLATS \\ COMBUSTIBLE RESIDUES CONTAMINATED \\ WITH PLUTONIUM METAL AND ORGANIC SOLVENTS
}

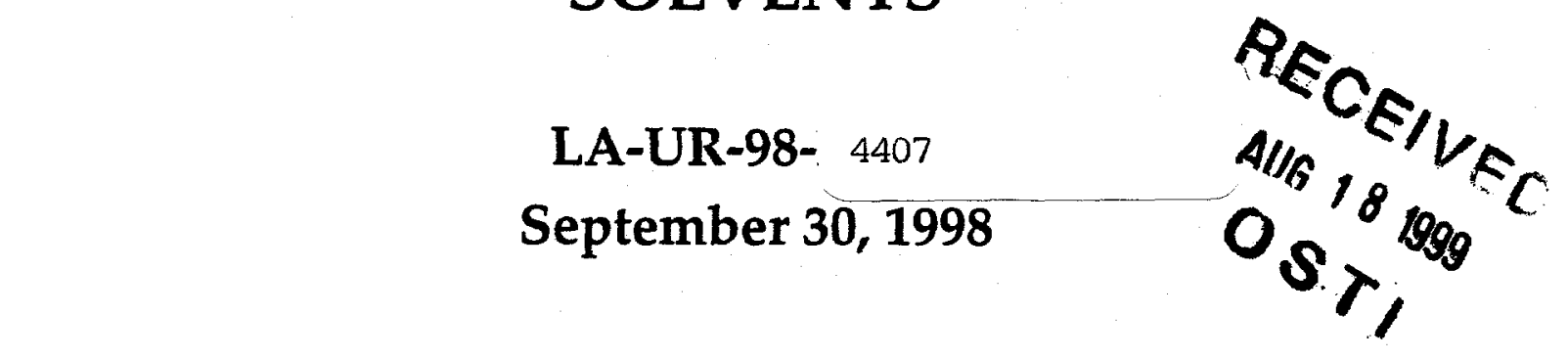

Scott M. Bowen ${ }^{\dagger}$, Michael R. Cisneros ${ }^{\dagger}$, Linda L. Jacobson $^{\dagger}$, Norman C. Schroeder ${ }^{\dagger}$, and Richard L. Ames ${ }^{+}$

${ }^{+}$CST-11

${ }^{++}$NMT-2

\begin{abstract}
This report describes tests on a proposed flowsheet designed to stabilize combustible residues that were generated at the Rocky Flats Environmental Technology Site (RFETS) during the machining of plutonium metal. Combustible residues are essentially laboratory trash contaminated with halogenated organic solvents and plutonium metal. The proposed flowsheet, designed by RFETS, follows a glovebox procedure that includes 1) the sorting and shredding of materials, 2) a low temperature thermal desorption of solvents from the combustible materials, 3) an oxidation of plutonium metal with steam, and 4) packaging of the stabilized residues. The role of Los Alamos National Laboratory (LANL) in this study was to determine parameters for the low temperature thermal desorption and steam oxidation steps. Thermal desorption of carbon tetrachloride $\left(\mathrm{CCl}_{4}\right)$ was examined using a heated air stream on a Rocky Flats combustible residue surrogate contaminated with $\mathrm{CCl}_{4}$. Three types of plutonium metal were oxidized with steam in a LANL glovebox to determine the effectiveness of this procedure for residue stabilization. The results from these LANL experiments are used to recommend parameters for the proposed RFETS stabilization flowsheet.
\end{abstract}




\section{DISCLAIMER}

This report was prepared as an account of work sponsored by an agency of the United States Government. Neither the United States Government nor any agency thereof, nor any of their employees, make any warranty, express or implied, or assumes any legal liability or responsibility for the accuracy, completeness, or usefulness of any information, apparatus, product, or process disclosed, or represents that its use would not infringe privately owned rights. Reference herein to any specific commercial product, process, or service by trade name, trademark, manufacturer, or otherwise does not necessarily constitute or imply its endorsement, recommendation, or favoring by the United States Government or any agency thereof. The views and opinions of authors expressed herein do not necessarily state or reflect those of the United States Government or any agency thereof. 


\section{DISCLAIMER}

Portions of this document may be illegible in electronic image products. Images are produced from the best available original document. 
LA-UR- $\quad 98-4407$

Approved for public release;

distribution is unlimited.

Title:

Stabilization of Rocky Flats combustible residues contaminated with plutonium metal and organic solvents

Author(s):
Submitted to:

Scott M. Bowen

Michael R. Cisneros

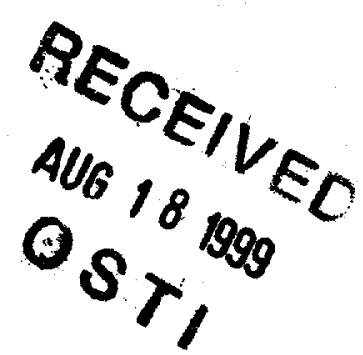

Linda L. Jacobson

Norman C. Schroeder

Richard L. Ames

\section{Los Alamos}

\section{NATIONAL LABORATORY}

Los Alamos National Laboratory, an affirmative action/equal opportunity employer, is operated by the University of California tor the U.S. Department of Energy under contract W-7405-ENG-36. By acceptance of this article, the publisher recognizes that the U.S. Government retains a nonexclusive, royalty-free license to publish or reproduce the published form of this contribution, or to allow others to do so, for U.S. Government purposes. Los Alamos National Laboratory requests that the publisher identify this article as work performed under the auspices of the U.S. Department of Energy. Los Alamos National Laboratory strongly supports academic freedom and a researcher's right to publish; as an institution, however, the Laboratory does not endorse the viewpoint of a publication or guarantee its technical correctness. 


\section{TABLE OF CONTENTS}

ABSTRACT

TABLE OF CONTENTS

LIST OF TABLES

LIST OF FIGURES

LIST OF AC̈RONYMS

BACKGROUND

Stabilization Criteria

RFETS Flowsheet

Parr ${ }^{\circledR}$ Reactor System

LANL Demonstration and Testing

EXPERIMENTAL

Preparation of Surrogate

Preparation of Cutting Oils

Preparation of Dry Surrogate

Preparation of Wet Surrogate

Preparation of Wet Surrogate with Carbon Tetrachloride

Low Temperature Thermal Desorption Experiments

Experimental Setup

Desorption Procedures

Trapping of Carbon Tetrachloride

Carbon Tetrachloride Analysis

Reheating of Surrogate with Hot Water

Plutonium Oxidation Experiments

Glovebox Reactor

Plutonium Metal Samples

Plutonium Metal Analysis

Small Scale Oxidation vs. Time Experiments

Determination of Metal Content in a Plutonium/Surrogate Sample

Differential Thermal Analysis

RESULTS AND DISCUSSION

Low Temperature Carbon Tetrachloride Desorption Experiments

Reheating of Surrogate with Hot Water

CONCLUSIONS

Carbon Tetrachloride Desorption

Water Additions

Plutonium Oxidation

Application of LANL Results to RFETS

System Configuration

Batch Size and Batch Preparation

Desorption of Volatile Organic Material 36

Plutonium Oxidation 


\section{LIST OF TABLES}

Table 1. Dry Surrogate Composition

Table 2. Average Maximum Surrogate Temperature as a Function of Water Added

Table 3. Percent Metal in Plutonium Metal Types Before Oxidation 27

Table 4. Percent Metal in Plutonium Metal Types After Oxidation 29

Table 5. Percent Oxidation vs. Time 30

Table 6. RFETS Operating Parameters for Stabilizing Combustible 36 Residues

\section{LIST OF FIGURES}

Figure 1. RFETS Flowsheet for Stabilizing Combustibles Residues

Contaminated with Plutonium Metal and Organic Solvents

Figure 2. Parr@ Reactor System

Figure 3. Two Gallon Parr ${ }^{\circledR}$ Reactor Used for Carbon Tetrachloride Desorption Experiments

Figure 4. Apparatus for Small Scale Steam Oxidation Experiments 15

Figure 5. Representative Heating Profile for No Induction Conditions 17

Figure 6. Representative Heating Profile for Induction Conditions 18

Figure 7. Carbon Tetrachloride Desorption Experiments Using 19 Induction Conditions

Figure 8. Heating Profiles for Addition of Water to Surrogate after 21 Carbon Tetrachloride Removal

Figure 9. Temperature Profile for the Injection of $500 \mathrm{~g}$ of $90^{\circ} \mathrm{C}$ Water into $25^{\circ} \mathrm{C}$ Wet Surrogate

Figure 10. Temperature Profile for the Injection of $600 \mathrm{~g}$ of $90^{\circ} \mathrm{C}$ Water 24 into $25^{\circ} \mathrm{C}$ Wet Surrogate

Figure 11. Percent Metal vs. Time for Unoxidized Plutonium Turnings 26

Figure 12. Percent Plutonium Metal in the Oxidized Metals as a 28 Function of Time for the Two Hour Oxidation

Figure 13. Percent Oxidation vs. Time for Each Type of Metal 31

Figure 14. Differential Thermal Analysis Plot for Oxidized Plutonium 32 Turnings and Surrogate 


\section{LIST OF ACRONYMS}

CST

Chemical Science and Technology

DOT

Department of Transportation

DTA

Differential Thermal Analysis

HEPA

High-Efficiency Particulate Air

ISSC

Interim Safe Storage Criteria

LANL

Los Alamos National Laboratory

NMT

RFETS

Nuclear Materials Technology

PI

Rocky Flats Environmental Technology Site

Pressure Indicator

PID

Proportional/Integral/Derivative

PLC

Process Logic Controller

STP

Standard Temperature and Pressure

TE

Temperature Element (thermocouple)

TRU

Transuranic

WIPP-WAC

Waste Isolation Pilot Plant Waste Acceptance Criteria 


\section{BACKGROUND}

During plutonium machining operations, the Rocky Flats Environmental Technology Site (RFETS) generated approximately 2.5 metric tons (145 drums) of combustible residues. Combustible residues are a heterogeneous mix of cellulosic (paper, towels, coveralls, etc.) and rubber materials (booties, gloves, etc.) that are essentially the trash coming from the machining operations. These residues are considered high risk because they contain solvents (predominantly carbon tetrachloride, $\mathrm{CCl}_{4}$ ), cutting oils, and pyrophoric plutonium metal. The core unit operations of the proposed combustible residues stabilization process consists of a low temperature thermal desorption step to remove volatile organic contaminants followed by a steam passivation step to convert plutonium metal to the oxide.

Stabilization Criteria: The product of the combustible residues stabilization process is required to meet a strict set of criteria identified by a number of sources such as the Criteria for Interim Safe Storage (ISSC) of Plutonium-Bearing Solid Materials, ${ }^{1}$ the Waste Isolation Pilot Plant Waste Acceptance Criteria (WIPP-WAC), ${ }^{2}$ and Department of Transportation (DOT) regulations. ${ }^{3}$ Listed below is a summary of the criteria that the stabilized combustible residues need to meet.

- No gas generation should occur when the stabilized product is immersed in water.

- The headspace of the 55 gallon drum containing the stabilized product should have less than $7510 \mathrm{ppm} \mathrm{CCL}_{4}$.

- The free liquid in the 55 gallon drum containing the stabilized product should be less than 2 liters with a $\mathrm{pH}$ between 2 and 12 .

- The stabilized product can not be pyrophoric.

- The Differential Thermal Analysis (DTA) of the stabilized product can not have an exotherm below $60^{\circ} \mathrm{C}$.

RFETS Flowsheet: RFETS personnel proposed a flowsheet for stabilizing the combustible residues. Details of the RFETS stabilization process, illustrated in Figure 1, include opening fifty-five gallon drums of combustible residues in a 


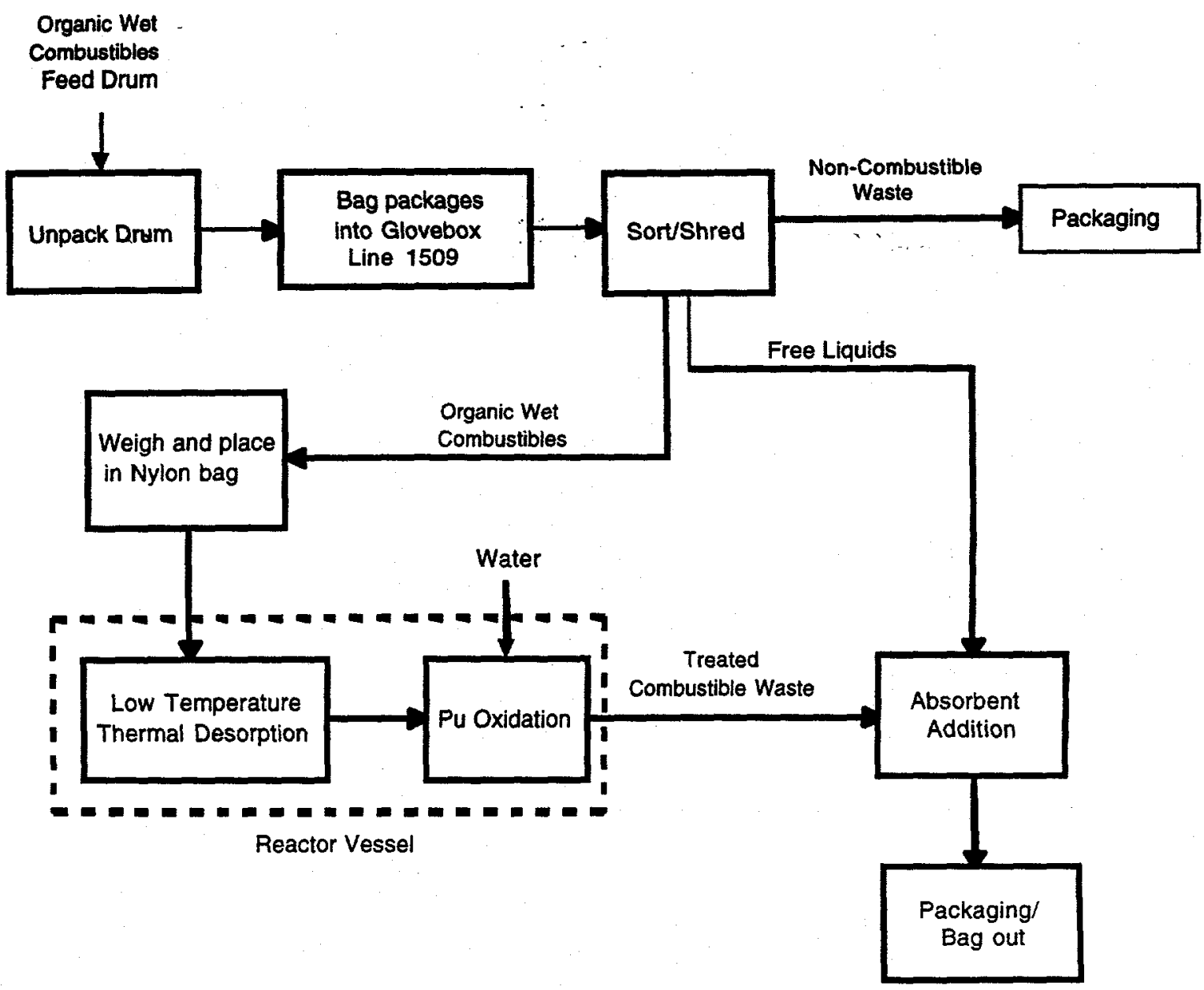

Figure 1. RFETS Flowsheet for Stabilizing Combustibles Residues Contaminated with Plutonium Metal and Organic Solvents.

contamination control area, bagging the drum contents, and transferring them into a glovebox. Within the glovebox, non-combustible material will be separated from the combustible residues; the combustible feed materials will then be mechanically shredded into 0.25 to 1 inch square debris. Small batches of the shredded combustible material (500 grams) will be placed into nylon mesh bags and loaded into 2 gallon Parr ${ }^{\circledR}$ pressure reactors; five reactors will be used in the process. Volatilization of organic solvent contaminants will be achieved by low temperature thermal desorption either under slight vacuum or with an air or nitrogen flow. The reactor will be sealed after thermal desorption and steam or hot water will be introduced into the vessel. Steam is used to convert the plutonium metal to a nonpyrophoric plutonium oxide. After a given time at the passivation temperature, the vessel and contents will be cooled, the vessel vented, and the combustible material removed. Finally, the treated combustibles will be packaged with an inert absorbent material to absorb any free water and drummed for storage and eventual shipment to WIPP. 
Parr Reactor System: The reactor system to be used at RFETS and used in LANL low temperature thermal desorption studies consists of a 2 gallon Parr pressure reactor made from C276 alloy and a Parr ${ }^{\circledR}$ model 4843 cascade controller. The system is described in Figure 2. The reactor heater system has an aluminum block

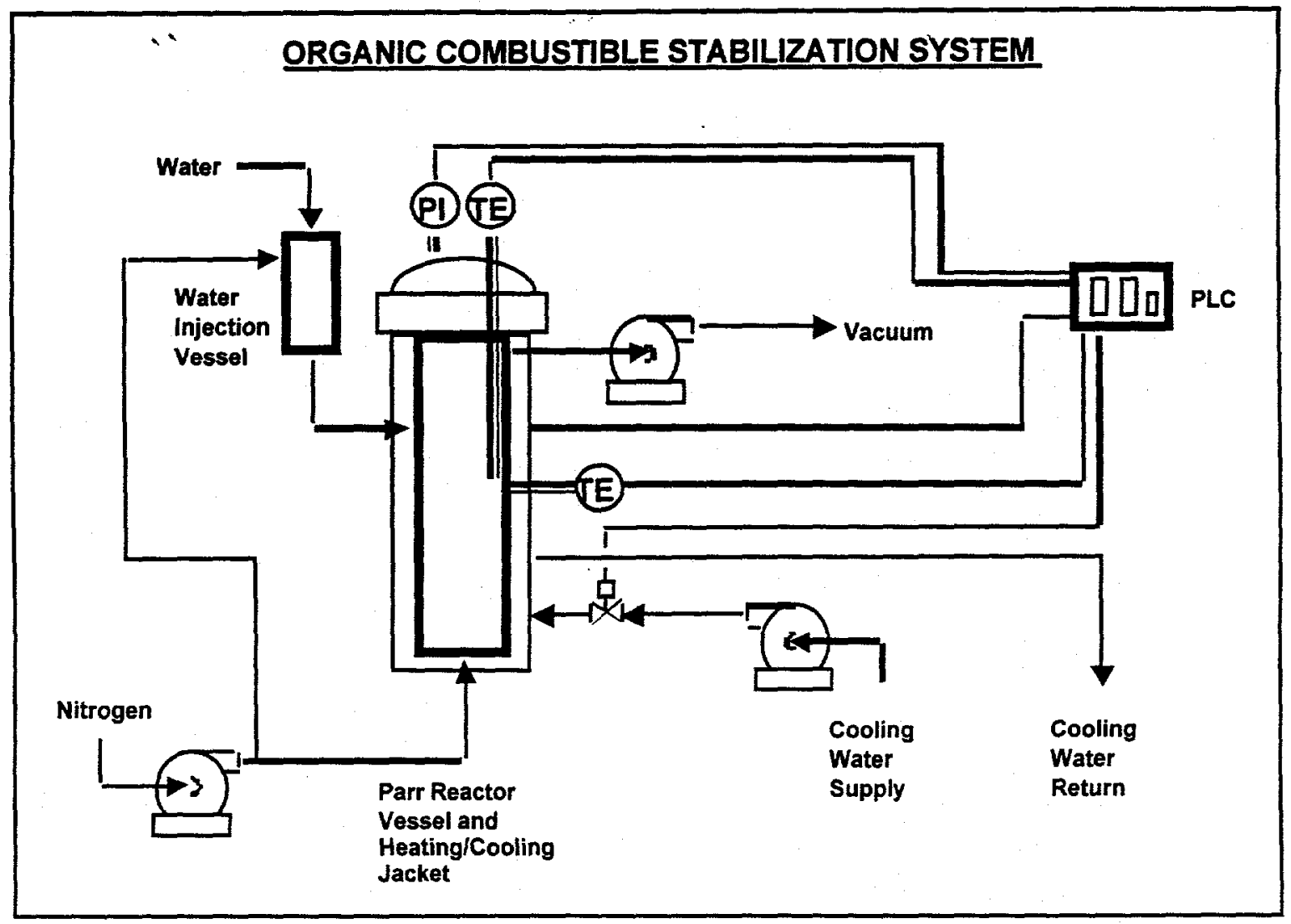

Figure 2. Parr® Reactor System.

electric heater with internal cooling water coil. The controller system uses internal and external thermocouples to maintain the internal reactor temperature at the desired process temperature. A stainless steel, 1-liter, vessel is used to introduce hot water into the reactor. The hot water is directed against the wall of the reactor to generate steam.

LANL Demonstration and Testing: Because many of the operating parameters for the RFETS process were undefined, it was necessary for LANL to determine the operational parameters for the two main steps of this process, the low temperature thermal desorption and the conversion of plutonium metal to oxide with steam. We have performed preliminary work on this project using cerium as a surrogate metal for plutonium. ${ }^{4,5}$ That work defined the temperature limits for operating the reactor. The low melting point of some of the plastic materials and the onset of charring by the cellulosic materials maximized the operational temperature at $130^{\circ} \mathrm{C}$. Fortunately the oxidation rate of pure plutonium metal by steam has a maximum at $110^{\circ} \mathrm{C} .^{6}$ Oxidation studies on cerium metal confirmed that oil coated 
cerium is oxidized slowly by boiling water or steam at ambient pressure. At the elevation in Los Alamos $\left(\sim 7500^{\prime}\right)$ this occurs at a temperature of $\sim 93^{\circ} \mathrm{C}$. With the Parr ${ }^{\circledR}$ reactor at $\sim 110^{\circ} \mathrm{C}$ and $10-20 \mathrm{psi}$, we were able to oxidize 1 to 2 grams of oil coated cerium in 2 hours. In addition, this work determined that an equal weight of water was required to completely wet the combustible residue surrogate material. This information was useful for setting up the thermal desorption and plutonium metal oxidation experiments described in this report. The work described below is for "wet surrogate" (oil coated cellulosic and plastic materials) containing $\mathrm{CCl}_{4}$ or plutonium alloy. The report covers experiments on handling and dealing with the removal of $\mathrm{CCl}_{4}$ from wet surrogate and steam oxidation experiments that attempted to convert three sizes of plutonium metal (turnings, $>40$ mesh, and $<40$ mesh) to an oxide within the wet surrogate matrix. 


\section{EXPERIMENTAL}

\section{Preparation of Surrogate}

Preparation of Cutting Oils: The two cutting oils used in machining operations at RFETS were Texaco Transultex-A, a low viscosity cutting oil; and Texaco Transultex$\mathrm{H}$, a very high viscosity cutting oil. These were obtained from Berridge Distributing company in Sante Fe NM. A 50/50 weight percentage mix was prepared. This mixture will be referred to as the "cutting oil mix".

Preparation of Dry Surrogate: "Dry surrogate" was obtained from Safe Sites of Colorado located at the RFETS. The composition is given in Table 1. The weight percent of the components that make up the dry surrogate result in a 50/50 weight percent mix of cellulosic and plastic material. This material was shredded into 0.25 to 1 inch square debris.

Table 1. Dry Surrogate Composition.

\begin{tabular}{lc}
\multicolumn{1}{c}{ Material } & Weight Percent \\
\hline Kimwipes/Paper Towels & 50 \\
Polyethylene Bags & 18 \\
PVC Bags & 9 \\
Cotton Cloth/Coveralls & 8 \\
Rubber/Surgeon Gloves & 5 \\
Rubber Booties/Overshoes & 4 \\
Cloth Booties/Overshoes & 4 \\
Anti-C Coveralls & 1 \\
Tyvek's & 1 \\
Total & 100 \\
\hline
\end{tabular}

Preparation of Wet Surrogate: A 28.6 weight percent oil-loaded surrogate was prepared by placing $4500 \mathrm{~g}$ of dry surrogate in a large polyethylene bag and adding $1800 \mathrm{~g}$ of the cutting oil mix, in small increments, while mixing thoroughly by hand. The homogenized oil-loaded surrogate is henceforth called "wet surrogate". The wet surrogate was stored in the sealed bag until needed.

Preparation of Wet Surrogate with Carbon Tetrachloride: An attempt was made to prepare a uniformly mixed surrogate $/ \mathrm{CCl}_{4}$ sample by slowly adding $200 \mathrm{~g}$ of $\mathrm{CCl}_{4}$ to $500 \mathrm{~g}$ of wet surrogate in a $2 \mathrm{~L}$ beaker and mixing. This was repeated until all the $\mathrm{CCl}_{4}$ was added to the wet surrogate. The mixture was then transferred to a hop sack (a $10^{\prime \prime} \times 24$ " coarse mesh nylon sack normally used for brewing beer, L. D. Carlson Kent, $\mathrm{OH}$ ) and the sack placed into a 5.25" x 13" Rocky Flats stainless steel reactor basket. During this process, 80 of the 200 grams of $\mathrm{CCl}_{4}$ were lost through 
evaporation. Because of this, all other additions of $\mathrm{CCl}_{4}$ were poured directly into the bagged wet surrogate in the reactor (see below). This minimized $\mathrm{CCl}_{4}$ evaporation during the addition and reduced the worker exposure to $\mathrm{CCl}_{4}$ but obviously gave an unmixed $\mathrm{CCl}_{4}$ /wet surrogate sample. The addition of $200 \mathrm{~g}$ of $\mathrm{CCl}_{4}$ to 500 gram portion of wet surrogate gave a 28.6 weight percent $\mathrm{CCl}_{4}$ loaded wet surrogate. The addition of $\mathrm{CCl}_{4}$ lowered the weight percent oil loading to $20.4 \%$.

\section{Low Temperature Thermal Desorption Experiments}

Experimental Setup: A series of experiments was conducted to determine the parameters for desorbing $\mathrm{CCl}_{4}$ from wet surrogate. A measured amount of wet surrogate $(500 \mathrm{~g})$ was added to a hop sack and placed in a Rocky Flats stainless steel reactor basket. The basket was placed inside a two gallon Parr ${ }^{\circledR}$ reactor that had been preheated to $50^{\circ} \mathrm{C}$. The experimental set up is shown in Figure 3. This set up 


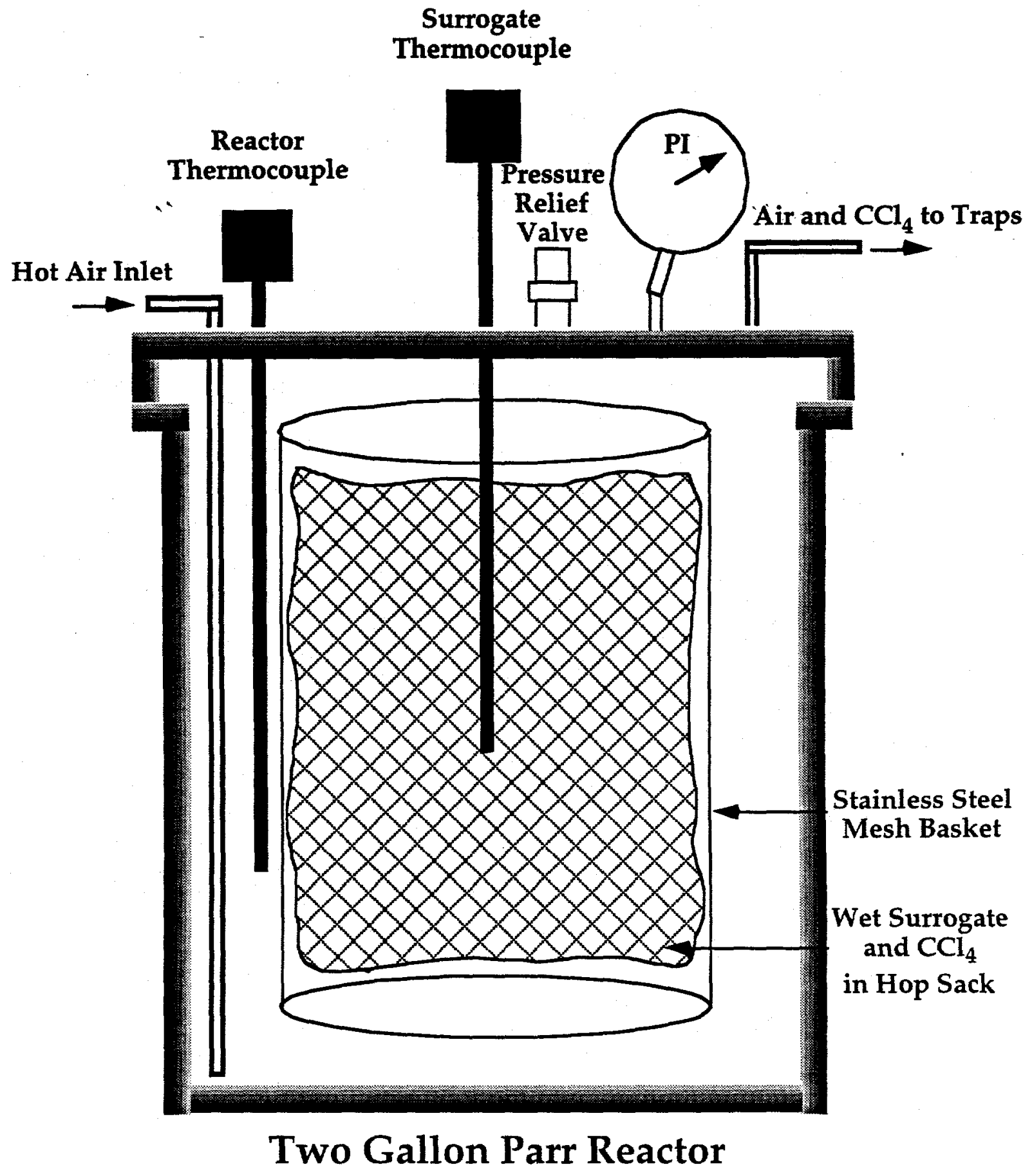

Figure 3. Two Gallon Parr ${ }^{\circledR}$ Reactor Used for Carbon Tetrachloride Desorption Experiments.

approximates the Rocky Flats system (Figure 2). The reactor was controlled with a Parr ${ }^{\circledR} 4842$ PID controller that sensed the internal reactor temperature through a thermocouple located between the wall of the reactor and the reactor basket. Two hundred grams of $\mathrm{CCl}_{4}$ were added to the surrogate after the basket was placed in the 
reactor. When placing the top of the reactor on, care was taken to put the surrogate thermocouple into the center of the surrogate to get as accurate a reading as possible of the internal surrogate temperature. Desorbed $\mathrm{CCl}_{4}$ was removed from the reactor by passing $110^{\circ} \mathrm{C}$ air through the reactor. Thermocouples were mounted on the inlet and outlet of the air purge lines. The reactor, surrogate, inlet air, exit air, and reactor pressure were monitored over time.. The surrogate was re-weighed at the end of each experiment to determine $\mathrm{CCl}_{4}$ weight loss.

Desorption Procedures: Carbon tetrachloride was removed by two experimental procedures.

- No Induction Procedure: In this procedure, $110^{\circ} \mathrm{C}$ air was passed through the reactor at $75 \mathrm{~L} / \mathrm{min}$ immediately after adding $\mathrm{CCl}_{4}$ to the wet surrogate and replacing the reactor lid. Although prior experiments had established that $\mathrm{CCl}_{4}$ desorption was more efficient at faster flow rates, $75 \mathrm{~L} / \mathrm{min}$ was the maximum achievable with the house air supply. Air was used because it provided an uninterrupted gas flow throughout the experiment. We observed no significant difference in the amount of $\mathrm{CCl}_{4}$ removed per unit time between nitrogen and air at the same flow rate. Immediately after the $\mathrm{CCl}_{4}$ was added, the reactor set point was raised to $110^{\circ} \mathrm{C}$.

- Induction Procedure: The second procedure included a one hour induction period after adding $\mathrm{CCl}_{4}$ to the wet surrogate. This was achieved by having the inlet and outlet air flow ports closed after sealing the reactor and keeping them closed for 1 hour. The reactor set point was raised to $110^{\circ} \mathrm{C}$ at the start of the induction period. The induction period's purpose was to allow $\mathrm{CCl}_{4}$ vapors to serve as a heat transfer fluid that would raise the internal surrogate temperature at a faster rates. Temperature/pressure data were collected during the induction period. After one hour, the average temperature of the surrogate was $\sim 80^{\circ} \mathrm{C}$. At this point the $75 \mathrm{~L} / \mathrm{min}$ air flow was started and temperature/pressure data collected over time.

Trapping of Carbon Tetrachloride: Attempts were made to trap desorbed $\mathrm{CCl}_{4}$ entrained in the off-gas in order to measure the effectiveness of our $\mathrm{CCl}_{4}$ removal process. The trapping system consisted of filters (to trap surrogate lint), copper cooling coils, $500 \mathrm{~mL}$ cold traps, Swagelok fittings, stainless steel tubing, flow valves, Tygon tubing and Dewars. A flexible tube was attached with a quick disconnect from the reactor unit to a 140 micron filter, 60 micron filter, and 7 micron HEPA filter series to trap surrogate lint. The filter series was then attached to a T-junction that allowed the flow to be directed to a specific trapping vessel; the air flow was directed to one trapping vessel at a time. Each junction was attached with Tygon tubing to a copper cooling coil that was then attached to a cold trap. The cold traps were vented into a laboratory hood. Three cooling schemes were examined: 
- A copper cooling coil cooled with ice water in series with a cold trap cooled in a dry ice/ethylene glycol $\left(-15^{\circ} \mathrm{C}\right)$ slush bath. The cold trap was weighed every 15 minutes.

- A copper cooling coil cooled with a dry ice/ethylene glycol $\left(-15^{\circ} \mathrm{C}\right)$ slush bath in series with a cold trap cooled with a dry ice/acetone $\left(-77^{\circ} \mathrm{C}\right)$ slush bath. The cold traps were weighed every 15 minutes.

- A copper cooling coil cooled with a dry ice/acetone $\left(-77^{\circ} \mathrm{C}\right)$ slush bath in series with a cold trap cooled with liquid nitrogen $\left(-196^{\circ} \mathrm{C}\right)$. This set up caused plugging of the cold trap outlet by condensed $\mathrm{CCl}_{4}$; for safety reasons, we abandoned this method.

Carbon Tetrachloride Analysis: Gas samples were taken from the head space of the Parr reactor by attaching a $100 \mathrm{~mL}$ gas tight syringe, fitted with a threaded syringe connector, that attached to the reactor through a quick disconnect fitting. Samples of the head space gas were taken after the post-desorption wet surrogate temperature reached $110^{\circ} \mathrm{C}$. At this point the reactor air flow was stopped and the reactor was sealed for 10 minutes. The syringe was attached, the valve to the sample port was opened, and a full syringe of sample was drawn. The sample was expelled into a hood to remove dead air space in the reactor. Three samples were then drawn into three separate $100 \mathrm{~mL}$ syringes. These samples were analyzed for $\mathrm{CCl}_{4}$ by GC/MS. The procedure is a DOE approved method for analyzing drum headspaces for volatile compounds. ${ }^{2}$ An average value of $634 \pm 160 \mathrm{ppm} \mathrm{CCl}_{4}$ was obtained for six samples from two induction experiments. The blank averaged $13 \pm 2 \mathrm{ppm} \mathrm{CCl}_{4}$ for an experiment following the induction procedure with no $\mathrm{CCl}_{4}$ added.

Reheating of Surrogate with Hot Water: After the $\mathrm{CCl}_{4}$ desorption, various amounts of hot $\left(>90^{\circ} \mathrm{C}\right)$ water were added to the hot $\left(\sim 95^{\circ} \mathrm{C}\right)$ wet surrogate to determine the amount of water that will be needed to quickly bring plutoniumcontaining desorbed surrogate to temperatures $>100^{\circ} \mathrm{C}$. After opening the reactor and adding the water to the center of the surrogate, the reactor was sealed and the surrogate temperature measured as a function of time. After these initial experiments, two hot water $\left(90^{\circ} \mathrm{C}\right)$ injections experiments were performed with the glovebox reactor configured similar to Figure 2. These experiments injected 500 and $600 \mathrm{~mL}$ of water onto the wall of a hot reactor containing 500 grams of $25^{\circ} \mathrm{C}$ wet surrogate; this was done to produce as much steam as possible in a short amount of time.

\section{Plutonium Oxidation Experiments}

Glovebox Reactor: A Parr ${ }^{\circledR}$ reactor system was installed in a Vacuum Atmospheres glovebox operating, under argon, at $0.25-0.5^{\prime \prime}$ (water column) of negative pressure. The system is similar to the one described in Figure 2. A Parr ${ }^{\circledR}$ Model 4843 cascade controller used the temperature of an internal thermocouple relative to an external thermocouple touching the outside of the reactor wall to adjusted the reactor temperature. These experiments were not preceded by a $\mathrm{CCl}_{4}$ desorption step because preliminary experiments showed that this led to excessive corrosion of the 
glovebox reactor, presumably by the reaction of $\mathrm{CCl}_{4}$ and water to produce $\mathrm{HCl}$. No air/nitrogen flowed through the reactor during the oxidation runs. A port at the top of the reactor was valved through a 7 micron HEPA filter to an external pump. Through appropriate valving, the pump was used to charge the water addition vessel with water and then inject it into the reactor. Heating tape around the vessel allowed the water to be warmed to $90^{\circ} \mathrm{C}$ prior to injection.

Plutonium Metal Samples: Three sizes of plutonium alloy samples were obtained from LANL's Plutonium Facility. Turnings, $\sim 0.3 \mathrm{~mm}$ in diameter, random length and curled, were obtained from machining a block of plutonium alloy. Two mesh sizes of plutonium alloy were prepared by sawing rods of plutonium alloy. The sawdust was sieved through a 40 mesh screen to produce $<40$ mesh and $>40$ mesh fractions. The $>40$ mesh material was potentially larger in diameter than the turnings, $\sim 0.6 \mathrm{~mm}$. All the samples were submerged in the cutting oil mix to prevent further oxidation after preparation and stored in the oil until use.

Plutonium Metal Analysis: The metal content of the three types of plutonium was determined by allowing weighed amounts ( $\sim 0.5$ grams) of each metal to react with 1 M-1.9 M sulfamic acid in a $290 \mathrm{~mL}$ Parr ${ }^{\circledR}$ pressure reactor. ${ }^{7}$ The $\mathrm{H}_{2}$ gas pressure generated from the reaction was monitored with time. The glovebox temperature was also taken with time. A normal run required at least 8 hours. The reactor volume (void volume) was corrected for the volume of reagents in the reactor.

Small Scale Oxidation vs. Time Experiments: Each plutonium experiment was configured as depicted in Figure 4. This consisted of a $100 \mathrm{~mL}$ support beaker that 


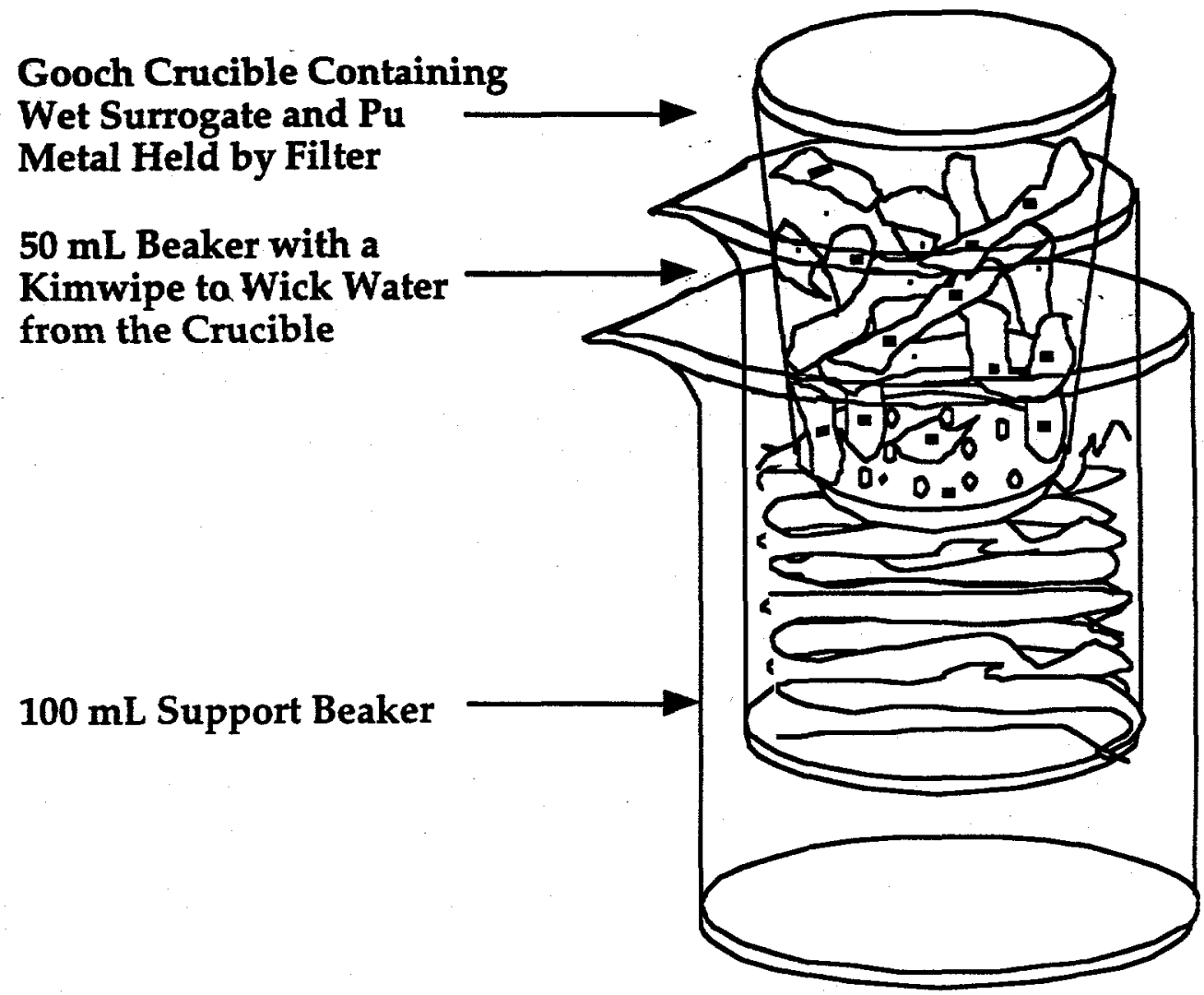

Figure 4. Apparatus for Small Scale Steam Oxidation Experiments.

held a $50 \mathrm{~mL}$ beaker containing a Kimwipe. The Kimwipe absorbed water from a 40 $\mathrm{mL}$ Coors Gooch crucible to prevent water from pooling within the plutonium/wet surrogate sample. The crucible contained a $9.0 \mathrm{~cm}$ Whatman $\# 541$ filter paper, folded in quarters, which held $\sim 0.5 \mathrm{~g}$ of plutonium metal mixed into $2.5 \mathrm{~g}$ of wet surrogate. For each oxidation run, three individual samples were prepared using the three plutonium metal types. Before mixing with the surrogate, the metal was washed with hexane, weighed, and then re-oiled with the cutting oil mix. The turnings were chopped before weighing so that they could be more easily mixed with the wet surrogate. One sample of each of the plutonium metal types was configured as in Figure 4, then placed into the reactor basket, which was then put inside the 2 gallon Parrß reactor which contained $100 \mathrm{ml}$ of water. The reactor was brought from ambient temperature to $110^{\circ} \mathrm{C}$, a process that took $\sim 90$ minutes. The internal temperature of the reactor above the samples, the temperature of reactor external wall, and the reactor pressure were monitored with time. Time for the oxidation started when the internal temperature reached $110^{\circ} \mathrm{C}$ and continued for the desired length of time. Reactor pressure at $\sim 110^{\circ} \mathrm{C}$ ranged between 25 and 40 psi during this time. When the oxidation time was complete, the reactor was cooled and the samples removed after the internal temperature was $<40^{\circ} \mathrm{C}$. The $\mathrm{pH}$ of the water and moist surrogate was taken with $\mathrm{pH}$ paper and the characteristics of the 
plutonium/surrogate sample noted. Black plutonium oxide produced from the oxidation smeared and discolored the wet surrogate material. This made it difficult to see how much metal was left in the sample. This also prevented recovering and weighing remaining unreacted metal fragments from the wet surrogate.

Determination of Metal Content in a Plutonium/Surrogate Sample: The filter containing the plutonium/wet surrogate sample, the Kimwipe, and the condensed water $(-20 \mathrm{~mL})$ from the $50 \mathrm{~mL}$ beaker was transferred to a $100 \mathrm{~mL}$ polypropylene beaker and then placed into a $290 \mathrm{~mL}$ Parr ${ }^{\circledR}$ reactor. The plutonium/ wet surrogate sample was tamped down to insure that it was submerged in the water. A $20 \mathrm{~mL}$ disposable polystyrene beaker containing $\sim 13 \mathrm{~mL}$ of either 1.0 or $1.9 \mathrm{M}$ sulfamic acid $\left(\mathrm{NH}_{2} \mathrm{SO}_{3} \mathrm{H}\right)$ was carefully placed on top of the surrogate material, and the reactor sealed. In some cases the sample was allowed to sit for 1 hour before mixing to determine if any gas generation occurred by the reaction of plutonium metal with water; in other cases, the sulfamic acid was immediately mixed with the sample. Pressure/temperature vs. time data were taken over the next 24 hours. After gas generation ceased, the sample was removed and examined. An absence of dark metal fragments and the presence of a purple solution indicated a complete reaction.

Differential Thermal Analysis: Samples consisting of wet surrogate, unoxidized plutonium turnings/wet surrogate, steam oxidized plutonium turnings/wet surrogate, steam oxidized $>40$ mesh plutonium/wet surrogate, and steam oxidized $<40$ mesh plutonium/wet surrogate were submitted for DTA analysis. Approximately 2.5 grams of wet surrogate and 0.3-0.5 grams of plutonium were used in these samples; the oxidation procedure was as described above. The oxidized samples went through a two hour steam oxidation. Systag Radix Solo model 3 ovens were used for the analyses, controlled by Systag RCI88 controllers. The analyses were performed over a temperature range of $25^{\circ} \mathrm{C}$ to $185^{\circ} \mathrm{C}$, at a linear scan rate of $2^{\circ} /$ minute. 


\section{RESULTS AND DISCUSSION}

Low Temperature Carbon Tetrachloride Desorption Experiments: Representative heating profiles for $\mathrm{CCl}_{4}$ removal under the no induction and induction conditions are shown in Figure 5 and 6 . Both methods attempted to desorb 200 grams of $\mathrm{CCl}_{4}$

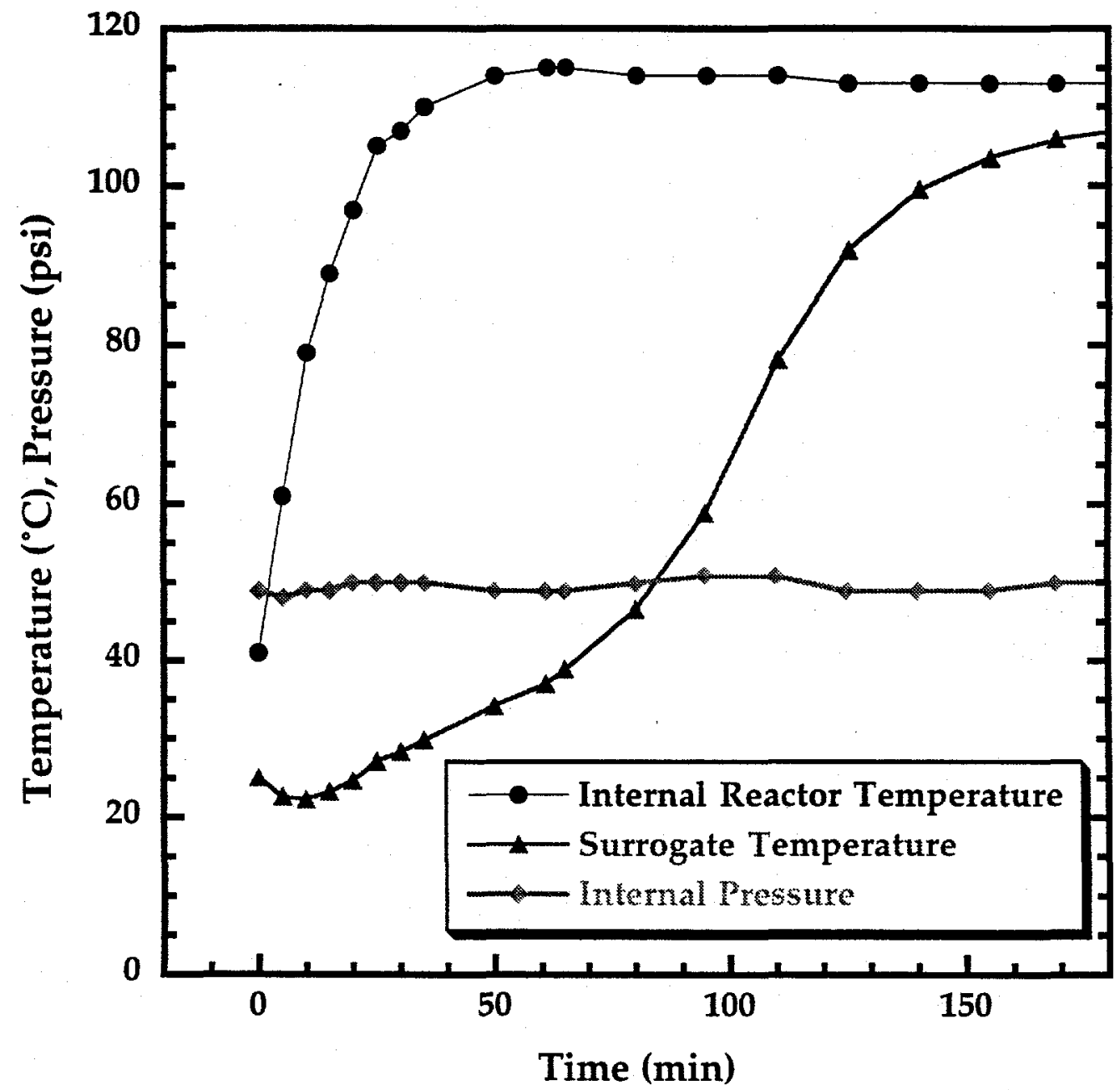

Figure 5. Representative Heating Profile for No Induction Desorption Conditions. 


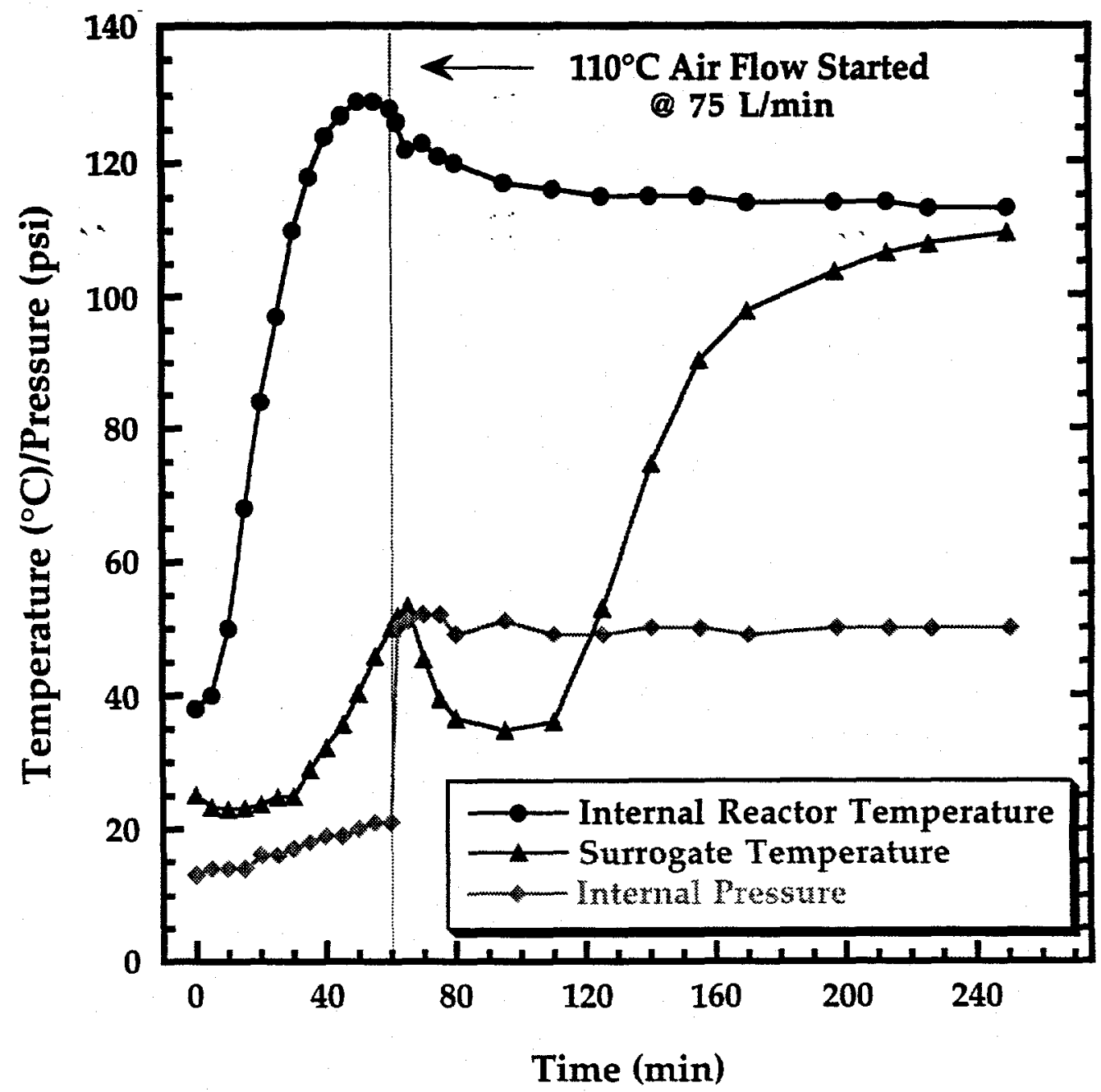

Figure 6. Representative Heating Profile for Induction Desorption Conditions.

from 500 grams of wet surrogate. The no induction method immediately began with a continuous flow of $110^{\circ} \mathrm{C}$ air at $75 \mathrm{~L} /$ minute as the reactor was brought from $50^{\circ} \mathrm{C}$ to $110^{\circ} \mathrm{C}$. The induction method delayed the air flow for one hour while the reactor was brought to temperature. Both methods showed an initial cooling of the surrogate during the first 20 minutes due to evaporative cooling as the $\mathrm{CCl}_{4}$ vaporized. The no induction method showed a slow rise in temperature in the surrogate temperature over the next 50 minutes. After 70 minutes, the rate of temperature rise increased, suggesting that most of the $\mathrm{CCl}_{4}$ was gone and evaporative cooling effects were no longer slowing the warming of the surrogate. The induction method was an attempt to speed up the desorption process by using volatilized $\mathrm{CCl}_{4}$ as a heat transfer fluid. Higher surrogate temperatures were obtained during the induction period, but as soon as the air flow was started evaporative cooling effects quickly dropped the surrogate temperature to a level 
comparable to the no induction method prior to its more rapid temperature rise beyond the 70 minute point.

Multiple experiments using both methods were run to determine the average time it took for the surrogate to reach $105^{\circ} \mathrm{C}$. The average time for 10 induction runs, including the 60 minutes induction period, was $192 \pm 43$ minutes. These runs are shown in Figure 7. This compares to $169 \pm 68$ minutes for 6 runs using the no

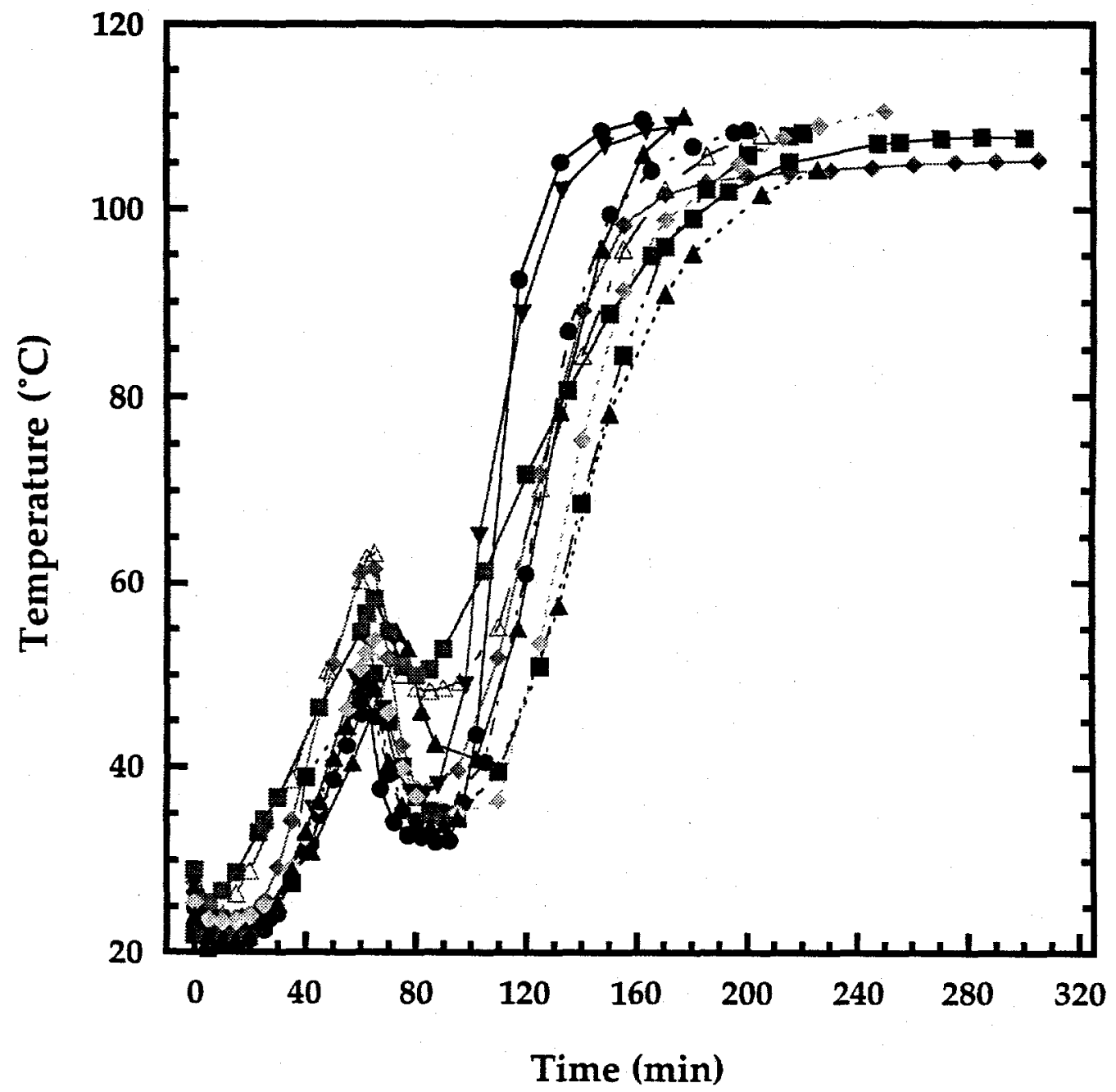

Figure 7. Carbon Tetrachloride Desorption Experiments Using Induction Conditions.

induction method. The large standard deviations obtained for the desorption methods are attributed to variability in the packing of surrogate, placement of $\mathrm{CCl}_{4}$ in the surrogate, and placement of thermocouple in surrogate. Surrogate composition and the size of the cut may also effect heat transfer. 
Since there are no plans to monitor the $\mathrm{CCl}_{4}$ desorption it maybe be necessary to run either desorption process for the average time plus one standard deviation. This is $\sim 235$ minutes for both methods. Thus there is no clear advantage to using either method. This time period may be too conservative since the head space analysis showed an average of $634 \pm 160 \mathrm{ppm} \mathrm{CCl}$ at the end of induction desorption, indicating that $>98 \%$ of the $\mathrm{CCl}_{4}$ was removed, which gave the surrogate a $\mathrm{CCl}_{4}$ content of $<0.7 \%$. This is well below the criteria of $7510 \mathrm{ppm} \mathrm{CCL}_{4}$ required for stabilized combustible residues. ${ }^{2}$

The criteria for $\mathrm{CCl}_{4}$ removal are not the only important concern. We experienced serious corrosion problems with the glovebox reactor and equipment. Much of this has to do with the moist environment that is produced by the oxidation step (see below). However, we eliminated desorption experiments in the glovebox because of the extra corrosion caused by $\mathrm{HCl}$ produced from the reaction of $\mathrm{CCl}_{4}$ and the water added in the subsequent steam oxidation step. Thus removing as much $\mathrm{CCl}_{4}$ as possible may increase the overall throughput of the process by eliminating some of the downtime required to repair equipment.

Other problems that need to be rectified are the trapping of $\mathrm{CCl}_{4}$. We were unsuccessful in doing this at the flow rates used in this process. We also noted that some oil distilled with both the $\mathrm{CCl}_{4}$ and water removal portions of our experiments. A thin film of cutting oil was also dispersed throughout the Parr ${ }^{\circledR}$ reactor outlet manifold.

Finally, the inefficiency of the desorption methods begs the question, are there more efficient methods for desorption? In our opinion, dispersal of the shredded material may actually be a more efficient desorption method than the scheme examined here. We lost 80 grams in 10 minutes trying to prepare homogenized $\mathrm{CCl}_{4} /$ surrogate samples. Since an off-gas system is required for the shredding operation, it might be a better idea to desorb $\mathrm{CCl}_{4}$ during this operation while the material is highly dispersed.

Reheating of Surrogate with Hot Water: After desorption of volatile organics from the combustible residues, the plutonium metal in these materials needs to be converted to an oxide by steam oxidation. Haschke, Allen, and Stakebake have shown that plutonium corrosion (oxidization) rates by steam achieve a maximum at $110^{\circ} \mathrm{C}^{6}$ The rate falls off at higher and lower temperatures. This is fortunate for the stabilization process since the material in the combustible residues either starts to char or melt above $130^{\circ} \mathrm{C}$. Obtaining and maintaining a temperature of $110 \pm 10^{\circ} \mathrm{C}$ is thus a crucial requirement for this process.

The maximum plutonium loading expected for actual RFETS combustible residues is expected to be $8 \%(\mathrm{w} / \mathrm{w})$. Stoichiometrically, only 6 grams of water would be required to oxidize the 40 grams of plutonium present in a 500 grams of combustible residues. Because the wet surrogate absorbs an equal weight of water and the fact that we have observed slow heat transfer from the reactor to the surrogate in our 
experiments, it was necessary to test the ability to achieve and hold the optimum operating temperature after water was added to the reactor.

Figure 8 shows how the temperature of the post- $\mathrm{CCl}_{4}$ desorption wet surrogate

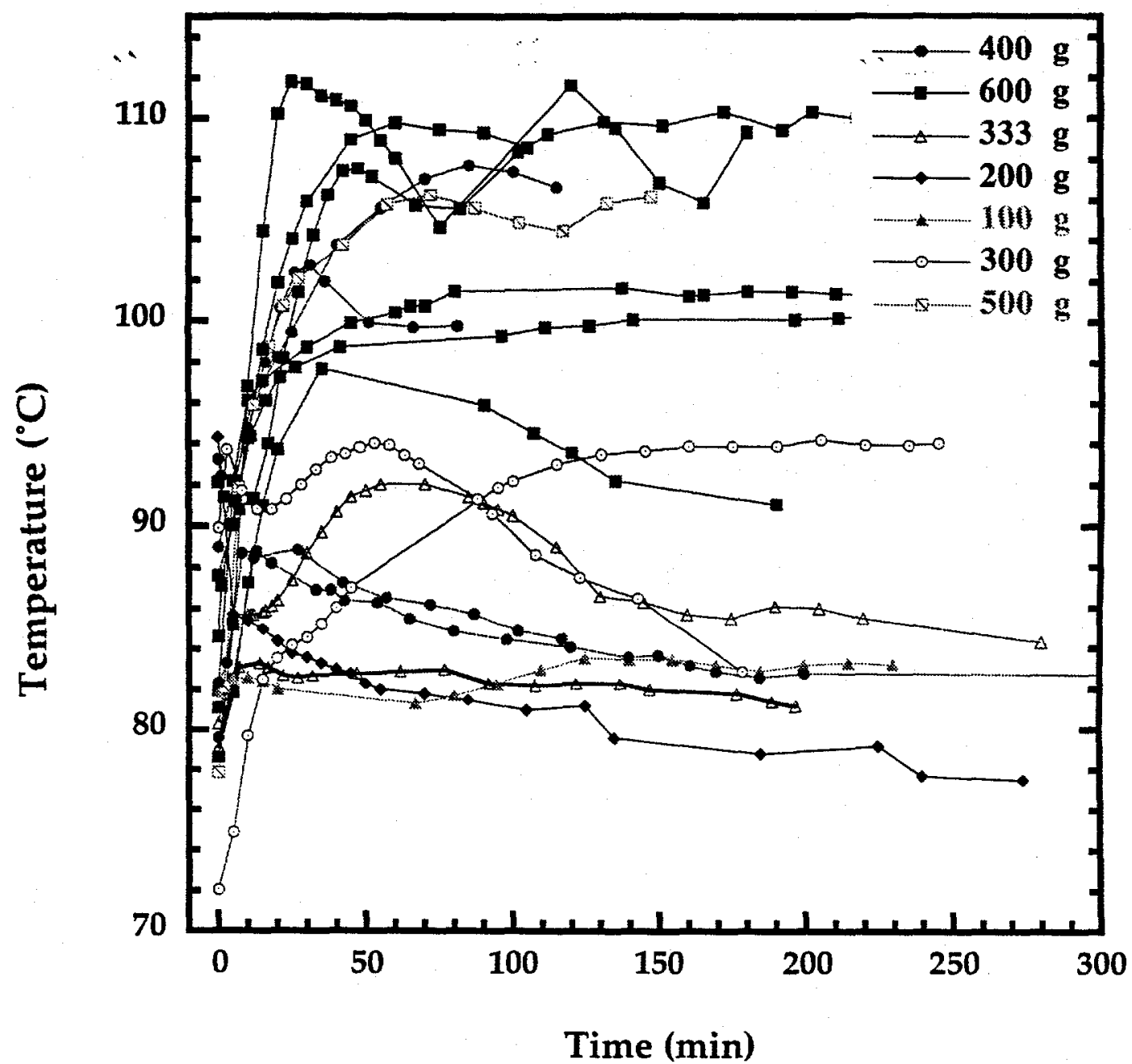

Figure 8. Heating Profiles for Addition of Water to Surrogate after Carbon Tetrachloride Removal.

varies with time as a function of the amount of water added. The average maximum temperatures measured for each water weight added are given in Table 2. 
Table 2. Average Maximum Surrogate Temperature as a Function Water Added.

\begin{tabular}{ccc} 
& Water Added $(\mathbf{g})$ & Maximum Temperature $\left({ }^{\circ} \mathbf{C}\right)$ \\
\hline & 100 & 94 \\
200 & 84 \\
300 & $94.1 \pm 0.1$ \\
333 & $88 \pm 6$ \\
400 & $97 \pm 10$ \\
500 & 106 \\
600 & $105 \pm 6$ \\
\hline
\end{tabular}

The figure shows that even though hot $\left(>90^{\circ} \mathrm{C}\right)$ water was being added to the hot $\left(\sim 95^{\circ} \mathrm{C}\right)$ wet surrogate, there was actually a $15-40^{\circ} \mathrm{C}$ decrease in the surrogate temperature; this was most likely an evaporative cooling effect. The maximum temperatures were generally reached within 100 minutes after the addition of the boiling water to the reactor. Variability in the observed maximum surrogate temperatures was due to differences in the heating behavior of the Parr® reactor controller from one experiment to the next and the effect of different placement of the thermocouple in the surrogate for each experiment. None of the water additions of $<400$ grams even reached $100^{\circ} \mathrm{C}$ and in addition tended to actually cool with time. Optimum temperatures $\left(>100^{\circ} \mathrm{C}\right)$ are achieved with the addition of $>400$ grams of water. Because the surrogate can absorb an almost equal weight of water and the fact that the two 400 gram additions showed a decrease in temperature with time suggest that $>500$ grams of water may be required to achieve and maintain the optimum oxidation temperatures. The 500 gram threshold is consistent with the water sorbing properties of the wet surrogate. An additional 100 grams of water may generate enough free steam to act as heat transfer fluid to maintain the operating temperature within the wet surrogate.

Figures 9 and 10 show the results of the injection of 500 and 600 grams of $90^{\circ} \mathrm{C}$ water 


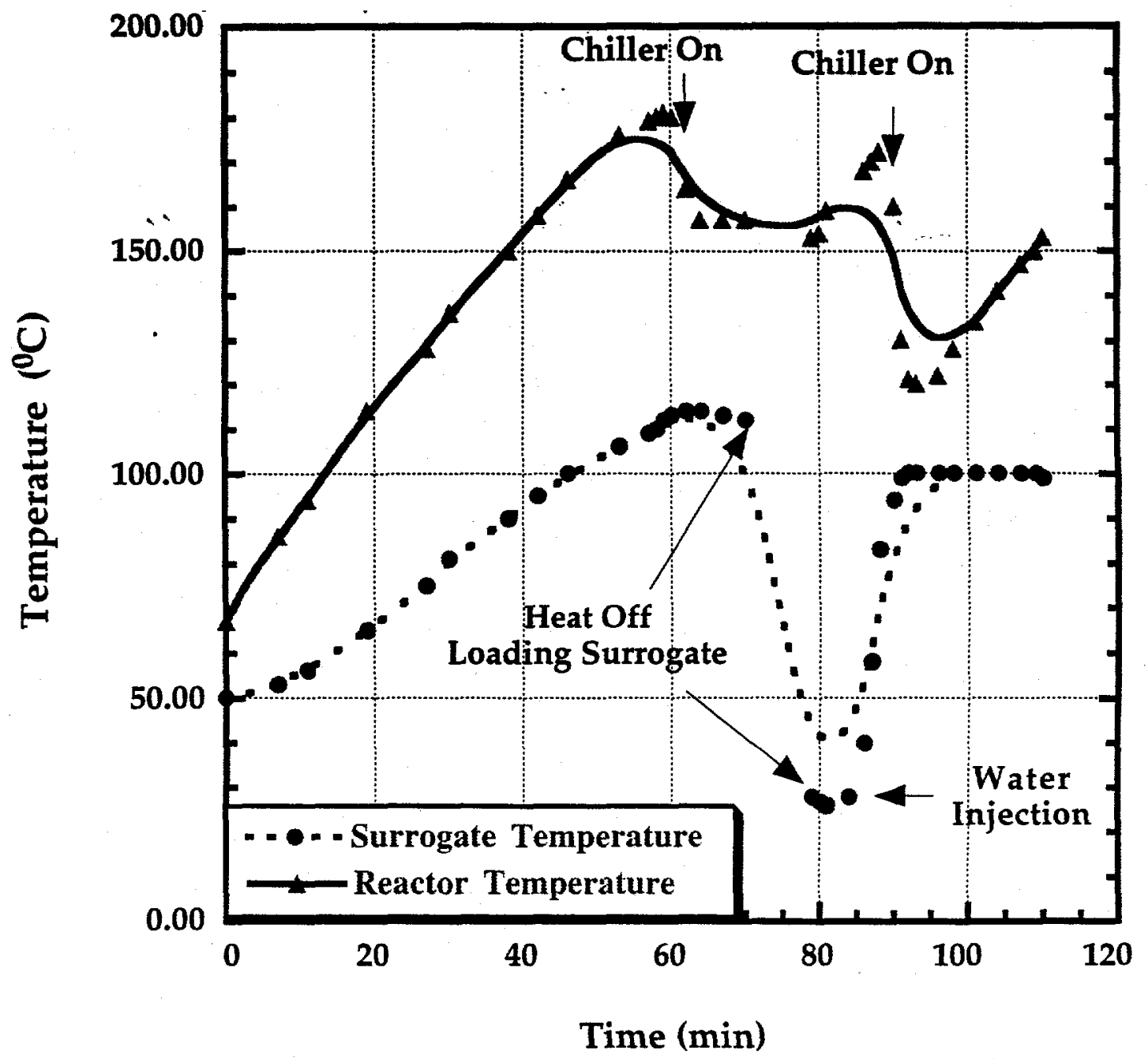

Figure 9. Temperature Profile for the Injection of $500 \mathrm{~g} \mathrm{of} 90^{\circ} \mathrm{C}$ Water into $25^{\circ} \mathrm{C}$ Wet Surrogate. 


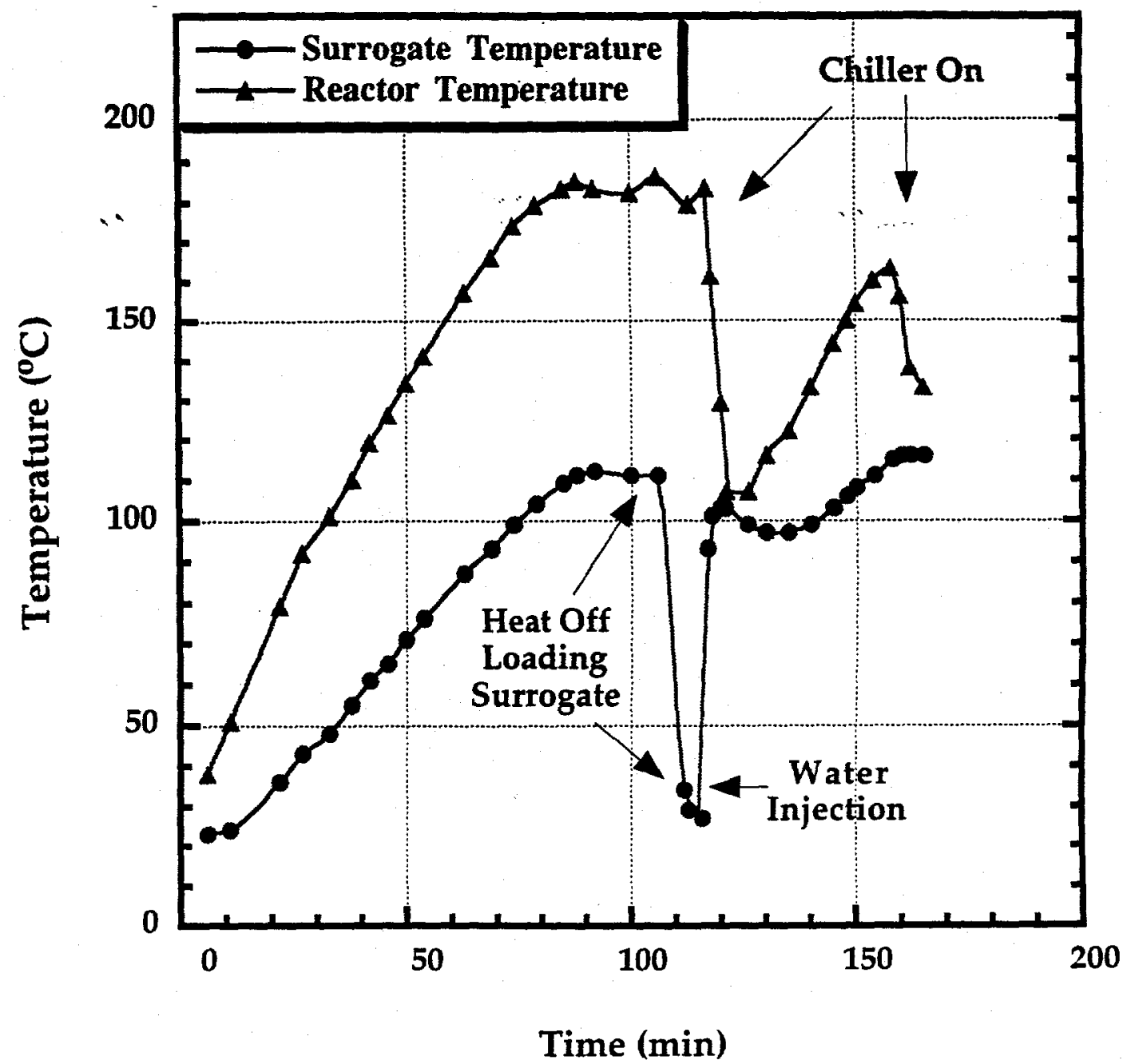

Figure 10. Temperature of Profile for the Injection of $600 \mathrm{~g}$ of $90^{\circ} \mathrm{C}$ Water into $25^{\circ} \mathrm{C}$ Wet Surrogate.

onto the walls of a hot reactor containing 500 grams of $25^{\circ} \mathrm{C}$ wet surrogate. These experiments were done in the glovebox reactor using apparatus similar to Figure 2. The 500 gram addition shows that the surrogate temperature rapidly increased from $25^{\circ} \mathrm{C}$ to $100^{\circ} \mathrm{C}$ in less than 10 minutes. However, the surrogate temperature remained at $100^{\circ} \mathrm{C}$ for 20 minutes even as the reactor controller continued heating the reactor in attempting to achieve a surrogate temperature of $110^{\circ} \mathrm{C}$. Apparently all of the water was sorbed by the surrogate and little was free to transfer heat from the reactor to the surrogate. In contrast, the 600 gram injection showed that the surrogate does respond to the reactor temperature. The extra water presumably allowed sufficient free steam to act as a heat transfer fluid in this system.

Six 500 gram samples of stabilized combustible residues will be shipped in each drum to WIPP. If more than $333 \mathrm{~mL}$ of water are required to carry out the oxidation 
of each sample, then a drying step will be needed to insure that the drum does not exceed the WIPP-WAC limit of two liters of free water per drum ${ }^{2}$. To remedy this problem we desorped excess water from the samples at an average rate of $3 \mathrm{~g} / \mathrm{min}$. Unfortunately, this will require more processing time than originally purposed by the RFETS flowsheet. This desorbed water will also produce a potential secondary waste water problem.

Plutonium Oxidation Studies: Oxidation of unstabilized plutonium metal with steam is reported to be rapid at $110^{\circ} \mathrm{C}$, with phase-stabilized plutonium reacting $10^{-5}$ times slower. ${ }^{6}$ RFETS combustible residues generated during machining activities are expected to be of the latter type. We therefore studied the oxidation of phasestabilized plutonium that was of three particle size distributions: turnings which were $~ 0.3 \mathrm{~mm}$ in diameter that were of random length and were curled, $>40$ mesh material, and $<40$ mesh fines. The turnings were cut to smaller length so we could make a more homogenous sample. The $>40$ mesh material actually had a larger diameter than the turnings $(0.6 \mathrm{~mm})$, but with a shorter length. The metal content of the three types of plutonium was determined by allowing weighed quantities of the alloys to react with an excess of sulfamic acid. Sulfamic acid reacts with plutonium metal according to the stoichiometry given in equation 1 . The pressure

$\mathrm{Pu}+3 \mathrm{NH}_{2} \mathrm{SO}_{3} \mathrm{H} \longrightarrow \mathrm{Pu}^{3+}+3 \mathrm{NH}_{2} \mathrm{SO}_{3}^{-}+1.5 \mathrm{H}_{2}$

from the $\mathrm{H}_{2}$ gas generated can be measured to determine the amount of metal present. The stoichiometry of this reaction was tested with cerium prior to using it as a tool to determine plutonium metal content, ${ }^{4,5}$ The expected amount of gas generated for the total oxidization of $\mathrm{Ce}$ to $\mathrm{Ce}^{3+}$ was measured in these preliminary experiments, indicating that this method is directly applicable to $\mathrm{Pu}$ oxidizing to $\mathrm{Pu}^{3+}$. Normally, $\mathrm{HCl}$ would be allowed to react with the metal, but the corrosive properties of $\mathrm{HCl}$ on stainless steel prevented us from performing these experiments in our glovebox and with the small Parr ${ }^{\circledR}$ reactor. Sulfamic acid is known to react quickly with plutonium metal without being corrosive to 316 stainless steel. ${ }^{7}$ The theoretical pressure of the gas generated was calculated in torr at STP according to equation 2 :

$$
\mathrm{P}(\text { torr })_{\text {theor }}=\frac{\mathrm{nRT}(760)(1.5)}{\mathrm{V}}
$$

where:

$\begin{array}{ll}\mathrm{n} & =\text { moles } \mathrm{Pu} \text { (assume pure } \mathrm{Pu}) \\ \mathrm{R} & =0.08205 \mathrm{~L} \text { atm } / \text { mole } \\ \end{array}$


The percent metal was calculated from equation 3:

$$
\% \text { Metal }=\frac{100\left[\mathrm{P}(\text { torr })_{\text {exp }}\right]}{\mathrm{P}(\text { torr })_{\text {theor }}}
$$

The experimental pressure, $\mathrm{P}(\text { torr })_{\exp }$ was adjusted to $273^{\circ} \mathrm{K}$ and corrected to standard pressure for the elevation at Los Alamos (at 7500 feet the normal pressure is $~ 571$ torr). All the sulfamic acid experiments were graphed as percent metal vs. reaction time. Figures 11 shows the results for unoxidized plutonium

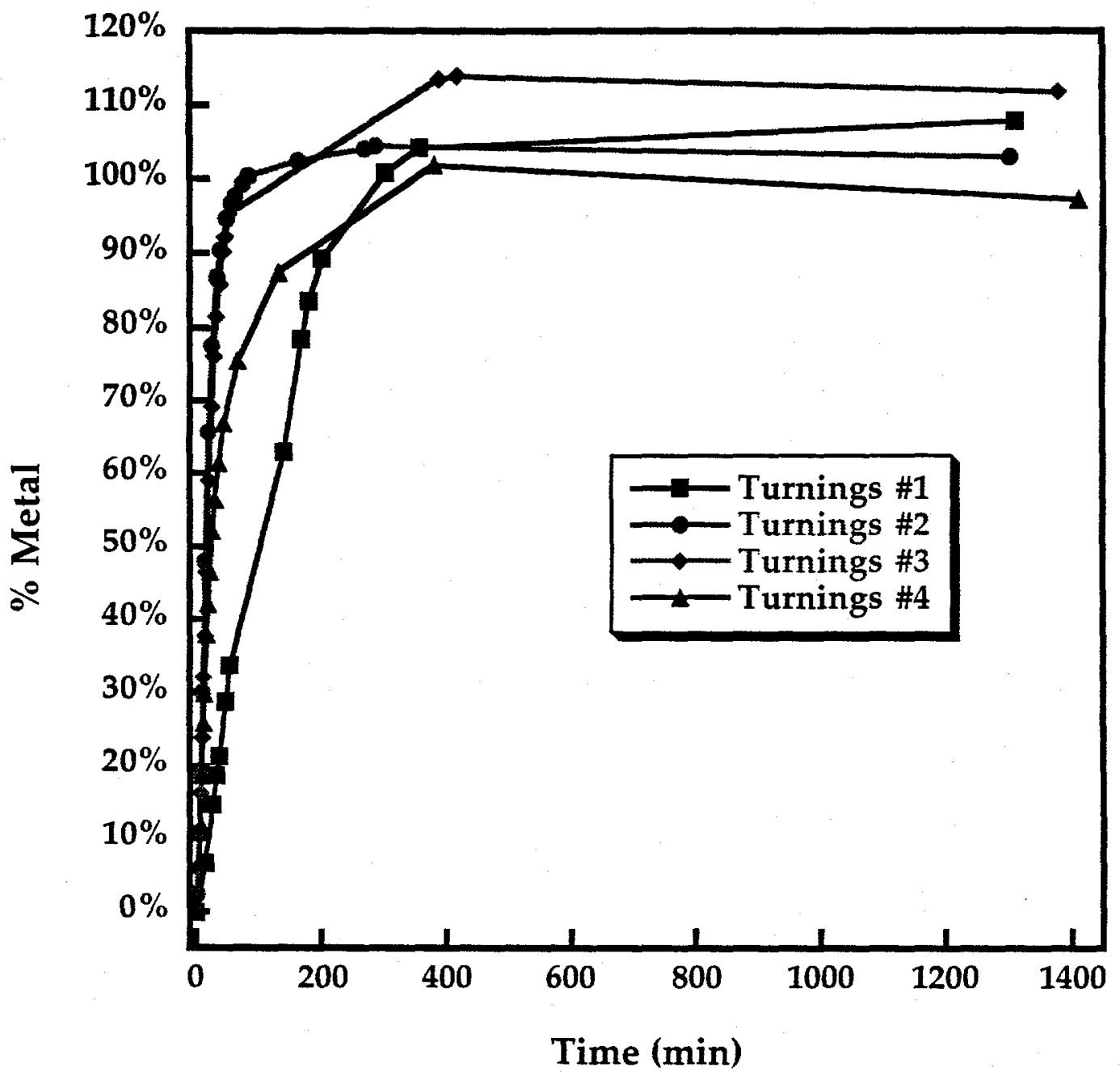

Figure 11. Percent Metal vs. Time for Unoxidized Plutonium Turnings. 
metal turnings. The unoxidized $>40$ mesh and $<40$ mesh materials had similar graphs. The final point was taken as the percent metal in the sample. The results for all three metal types are listed in Table 3 with the average plutonium metal

Table 3. Percent Metal in Plutonium Metal Types Before Oxidation.

\begin{tabular}{cccc} 
Rùn & Turnings & $>$ 40 Mesh & $<$ 40 Mesh \\
\hline 1 & 107.9 & 104.7 & 102.6 \\
2 & 103.0 & 111.7 & 90.5 \\
3 & 111.8 & 108.4 & \\
4 & 97.3 & 104.6 & \\
Average & 105.0 & 107.4 & 96.5 \\
$\pm 1 \sigma$ Error & 6.6 & 3.6 & 8.2 \\
\hline
\end{tabular}

content calculated with \pm one sigma error. Within experimental error, the three metals contain about the same percentage of plutonium. We obtained greater than $100 \%$ metal for the starting samples. This is probably due to a bias in the weighing of the plutonium metal. The error in the analyses is most likely due to normal experimental error but also to barometric pressure changes. Barometric readings were taken at the start of the experiment and used as a baseline for the entire dissolution period; the atmospheric pressures during experiments could have increased or decreased.

The sulfamic acid method was particularly useful for analyzing the post-oxidation samples. The plutonium in these samples was unrecoverable, not only because it was dispersed in the wet surrogate matrix, but also because the metal character had changed. The post-oxidation plutonium was covered with a sludge that would easily smear on anything it contacted. It would be impossible to recover the fine bits of metal from the sludge/wet surrogate matrix. In addition, the metal pieces that were observable appeared to be smaller and more fragile than the unoxidized metal. In fact, the sulfamic acid method was developed to make the analysis of these samples possible.

Previous oxidation experiments have noted two phenomena that necessitated the use of the apparatus shown in Figure 4. One, plutonium metal becomes passivated when submerged in water. Second, the steam reaction with the metal tends to break the metal into smaller fragments. The apparatus shown in Figure 4 allowed condensed water to drain from the plutonium/surrogate sample; the Kimwipe in the $50 \mathrm{~mL}$ beaker touching the bottom of the Gooch crucible initiated the flow of water from the crucible. The filter held the plutonium/surrogate sample and prevented fine metal from passing through the relatively large crucible pores and becoming submerged in the water that collected in the $50 \mathrm{~mL}$ beaker.

Three steam oxidation experiments were performed using the sample set-up shown in Figure 4. Each run included one sample of each metal type. The oxidation times 
at $110^{\circ} \mathrm{C}$ were $1,2,6$, and 18 hours. After removal from the reactor the contents of each sample was analyzed using the sulfamic acid method. Figures 12 plots

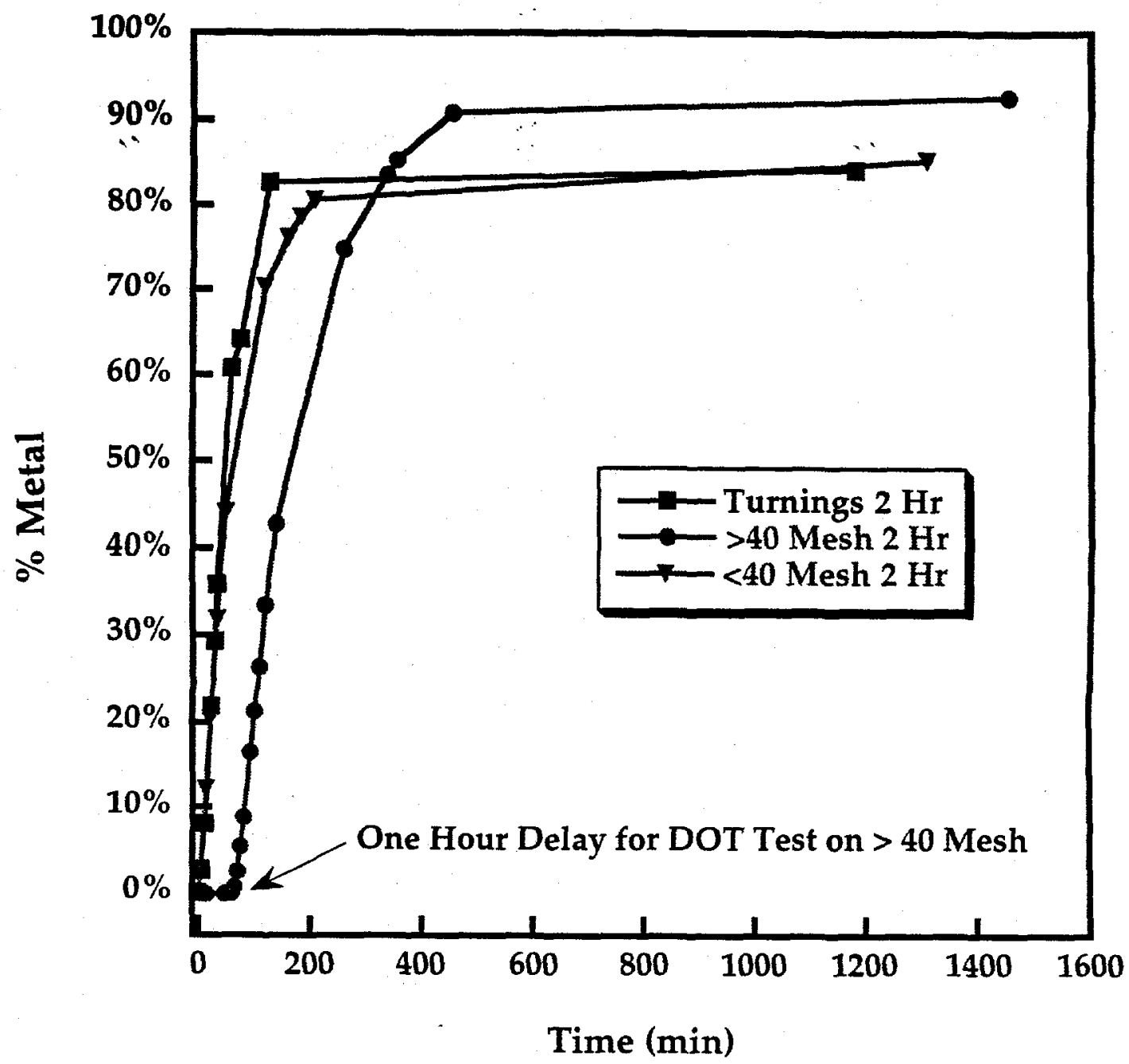

Figures 12. Percent Plutonium Metal in the Oxidized Metals as a Function of Time for the Two Hour Oxidation.

percent plutonium metal vs. time for the three metal types after a two hour oxidation. Similar plots were obtained for the other oxidation times. The $>40$ mesh curve includes a 1 hour delay before the sample was contacted with the sulfamic acid. This was a test to see if the post-oxidation sample would produce any gas when submerged in water. Little or no gas was observed in this test or with other samples that were subjected to this same treatment. Thus, we can say that the post-oxidation samples meet this DOT criterion. Table 4 summarizes the percent metal left after 
Table 4. Percent Metal in Plutonium Metal Types after Oxidation.

\begin{tabular}{|c|c|c|c|}
\hline $\begin{array}{l}\text { Oxidation Time } \\
\text { (Hours) }\end{array}$ & Turnings. & $>40$ Mesh & $<40$ Mesh \\
\hline $\begin{array}{r}1 \\
2 \\
6\end{array}$ & $\begin{array}{l}94.4 \\
84.2 \\
49.2\end{array}$ & $\begin{array}{l}98.4 \\
92.6 \\
45.2\end{array}$ & $\begin{array}{l}94.3 \\
85.3 \\
56.6\end{array}$ \\
\hline
\end{tabular}

the 1,2, and 6 hour oxidations of each metal type. There is not a drastic difference in reactivity of the three metal types even though they were different sizes. Longer oxidation times produced more of a sludge coating on the metal particles and resulted in smaller fragments of metal. The $\mathrm{pHs}$ of all oxidized samples were between 6.0 and 6.5 and therefore meet ISSC and WIPP-WAC standards for this criterion. Water that would temporarily pool in the crucible holding the sample could give variability to the results because it could passivate any metal that it submerges. Water pooling appeared to cause the failure of the 18 hour oxidation experiments. The 18 hour samples were wetter upon removal from the reactor than the shorter reaction time samples. All three metal types showed $\sim 100 \%$ metal remaining after the steam oxidation. If processing large amounts of surrogate (or Rocky Flats shredded residue), caution is advised as a very damp or saturated surrogate may have the same effect as pooled water on the sample. We realize that this statement is contrary to our advisement to use a large amount of water to get the combustible materials up to the optimum operating temperatures for the steam oxidation. What these statements mean is that a more specific water addition envelope may have to be defined for this process to operate correctly.

The percent oxidation was measured relative to an average value for each starting metal type and is calculated using equation 4 :

$$
\% \text { oxidation }=\frac{(\% \text { Metal })_{\text {initial }}-(\% \text { Metal })_{\text {final }}}{(\% \text { Metal })_{\text {initial }}}
$$

where:

$(\% \text { Metal })_{\text {initial }}=$ pre-oxidation $\%$ Pu metal

$(\% \text { Metal })_{\text {final }}=$ post-oxidation $\%$ Pu metal

Table 5 summarizes percent oxidation vs. time for the three metal types. Except for 
Table 5. Percent Oxidation vs. Time.

\begin{tabular}{|c|c|c|c|c|}
\hline $\begin{array}{c}\text { Oxidation } \\
\text { Time (Hours) }\end{array}$ & Turnings & $>40$ Mesh & $<40$ Mesh & $\begin{array}{c}\text { Ave. } \\
\pm 1 \text { s Error } \\
\end{array}$ \\
\hline $\begin{array}{l}1 \\
2 \\
6\end{array}$ & $\begin{array}{l}10.1 \\
19.9 \\
53.1\end{array}$ & \begin{tabular}{r}
8.3 \\
$\therefore \quad 13.8$ \\
\hdashline$\quad 57.9$ \\
\end{tabular} & $\begin{array}{r}2.3 \\
11.6 \\
41.3\end{array}$ & $\begin{array}{c}6.9 \pm 4.1 \\
15.1 \pm 4.3 \\
50.8 \pm 8.5\end{array}$ \\
\hline
\end{tabular}

the 6 hour value for the $>40$ mesh sample there appears to be a trend in the extent of oxidation with particle size that is the inverse of what would be expected; the percent oxidation decreases with particle size! Perhaps the expected surface area effect is being negated by surface oxides that coat all the metal types. This data has implications for the plutonium metal in the Rocky Flats combustible residues. Even if those materials contain plutonium much finer than 40 mesh, they may not be any more reactive than the plutonium used in these experiments. Figure 13 plots the percent oxidation vs. time for each type of metal. The average oxidation 


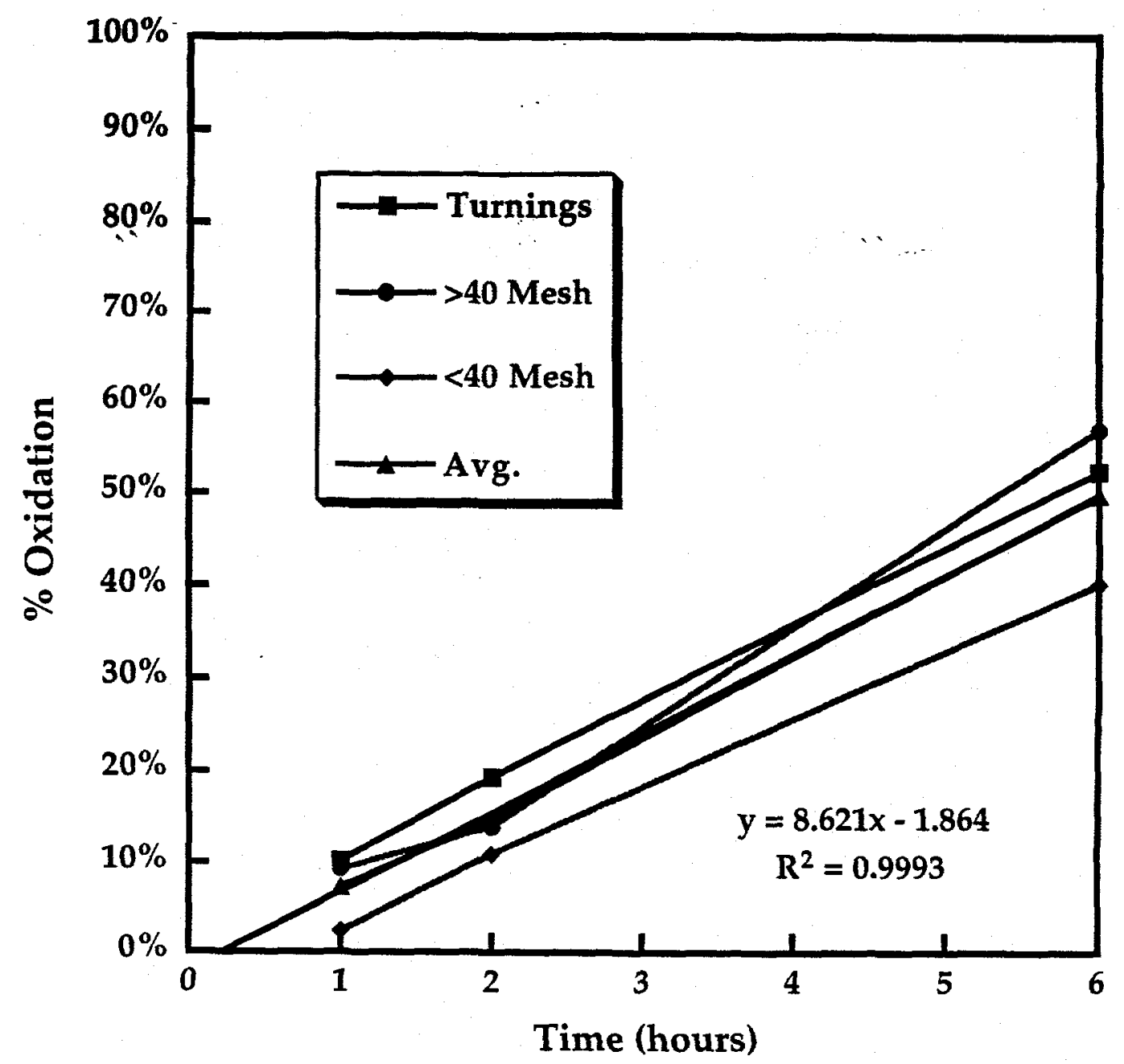

Figure 13. Percent Oxidation vs. Time for Each Type of Metal.

percentage for the three plutonium metal types increases linearly over 6 hours. Although the plutonium is becoming more finely divided with longer oxidation times, the linear percent oxidation curve suggests that the dispersal of the metal has no effect on the extent of oxidation. If fifty percent oxidation occurred in 6 hours, then an extrapolation of data suggests that complete oxidation might occur in 12 hours.

Haschke et. al. predict that a 0.5 gram sample of 40 mesh unstabilized plutonium would oxidize in 35 minutes. Oxidation of stabilized plutonium would be as much as $10^{-5}$ times slower. The oxidation of the stabilized plutonium metal types in this work is significantly higher than predicted. The fact that all three metal types oxidize at about the same rate and in linear fashion suggests the actual surface areas of these metals may be much higher than calculations based on the metal particle sizes. Perhaps microscopic cracks formed in the metals during machining and the 
surface areas of these cracks really account for a large surface area. This may account for the higher oxidation rate. If all the metal types have about the same surface areas from these types of cracks, the nearly uniform rate can be understood.

Our earlier oxidation experiments have shown that additives such as sulfamic acid, $\mathrm{H}_{2} \mathrm{O}_{2}$ or $\mathrm{CCl}_{4}$ can enhance the oxidation., ${ }^{4,5}$ The addition of additives is not considered an option for this process. However, residual $\mathrm{CCl}_{4}$ from the desorption process may react with water to produce $\mathrm{HCl}$, resulting in an enhanced oxidation. However, $\mathrm{HCl}$ causes reactor corrosion and could drop the $\mathrm{pH}$ of the product out of WIPP-WAC compliance.

We submitted five of our small scale ( $\sim .5$ grams plutonium) samples for DTA analysis. The samples were surrogate only, surrogate/plutonium with no oxidation, surrogate/plutonium turnings with a two hour oxidation, surrogate $/>40$ mesh plutonium with a two hour oxidation, and surrogate $/<40$ mesh plutonium with a two hour oxidation. The surrogate/oxidized plutonium turnings plot is shown in Figure 14. It is typical of the five analyses. All the oxidized samples passed the

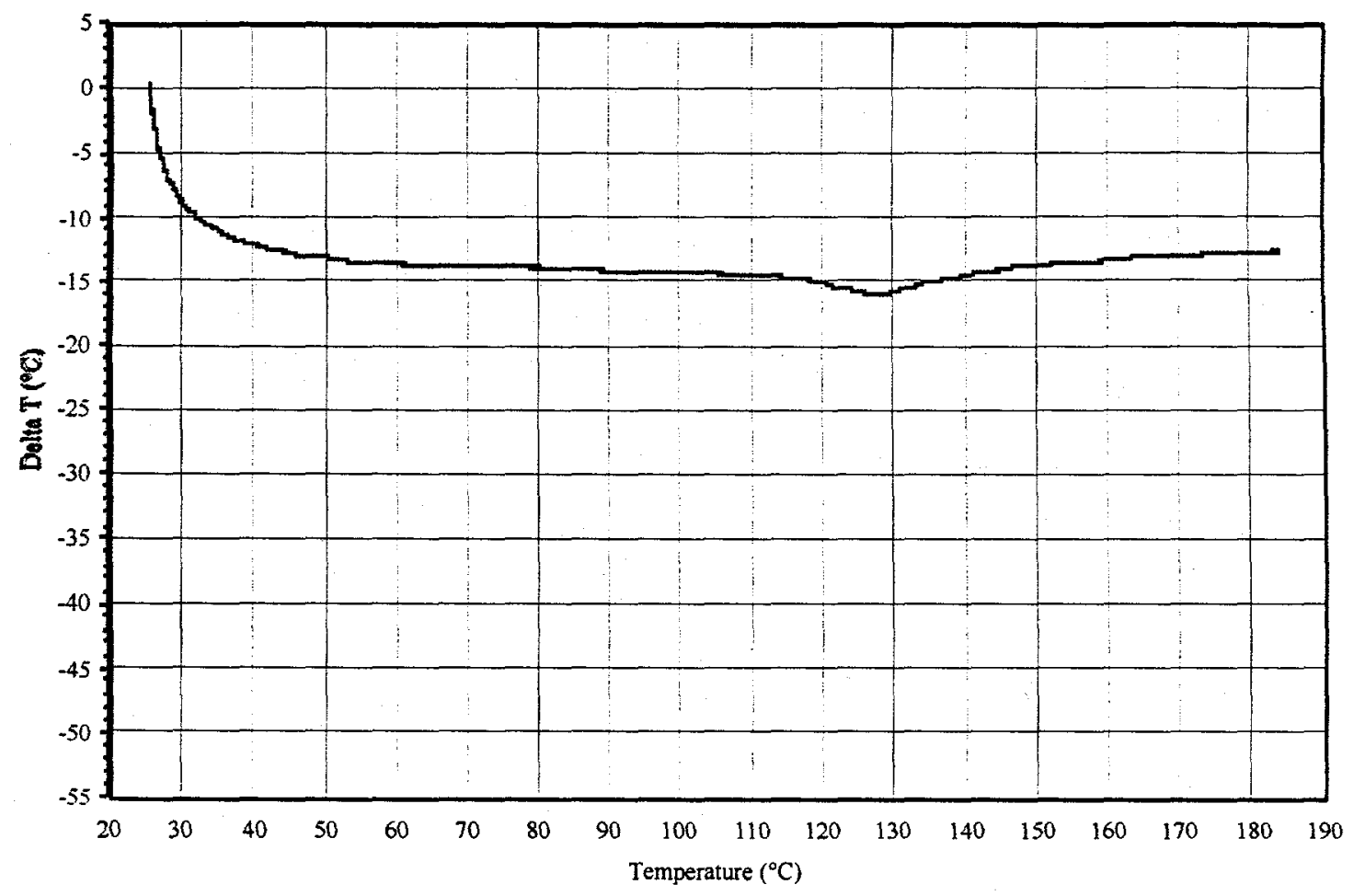

Figure 14. Differential Thermal Analysis Plot for Oxidized Plutonium Turnings and Surrogate.

Rocky Flats stabilization criterion of "not exothermic at below $60^{\circ} \mathrm{C}$." All sample baselines exhibit a slight endotherm of less than an absolute magnitude of $5^{\circ} \mathrm{C}$, that 
begins approximately between $120^{\circ} \mathrm{C}$ and $130^{\circ} \mathrm{C}$ and ends just before $140^{\circ} \mathrm{C}$. This is likely due to a common substance that is going through a phase change, such as a melt. In the surrogate only sample, this endotherm is a bit obscured by other events taking place. Beginning at $25^{\circ} \mathrm{C}$ and ending between $100^{\circ} \mathrm{C}$ and $110^{\circ} \mathrm{C}$ the same slow sweeping endotherm exists in all five samples. 


\section{CONCLUSIONS}

\section{Carbon Tetrachloride Desorption}

- $\mathrm{CCl}_{4}$ desòrption from the surrogate by heating to $110^{\circ} \mathrm{C}$ using the "induction" method took an average of $192 \pm 43$ minutes. This may be a slightly more consistent process than the method with "no induction".

- The large standard deviations for the desorption step may have been caused by variability in the packing of surrogate, placement of $\mathrm{CCl}_{4}$ in the surrogate, and placement of thermocouple in the surrogate. Surrogate composition and cut may have also affected heat transfer.

- An average of $634 \mathrm{ppm} \mathrm{CCl}$ remained in the headspace of the reactor at the end of the "induction" method, indicating greater than $98 \%$ of the $\mathrm{CCl}_{4}$ was removed.

- $\mathrm{CCl}_{4}$ trapping was inefficient. Using various trapping schemes, only a small amount of the total $\mathrm{CCl}_{4}$ removed from the surrogate was trapped.

- Some oil distilled with both the $\mathrm{CCl}_{4}$ and water removal portions of our experiments. A thin film of cutting oil was also dispersed throughout the Parr ${ }^{\circledR}$ reactor outlet manifold.

- Dispersal of the shredded material may actually be a more efficient desorption method than the scheme examined here. We lost 80 grams in 10 minutes trying to prepare homogenized $\mathrm{CCl}_{4} /$ surrogate samples.

- We found no difference between using air or nitrogen for the $\mathrm{CCl}_{4}$ desorption.

\section{Water Additions}

- The volume of hot water added to the surrogate affected the maximum surrogate temperature.

- The maximum temperatures were generally reached within 100 minutes after the addition of the boiling water to the reactor.

- Variability in the observed maximum surrogate temperatures was due to differences in the heating behavior of the Parr ${ }^{\circledR}$ reactor controller from one experiment to the next and the effect of different placements of the thermocouple in the surrogate for each experiment.

- In general, $>500$ grams of hot water were needed to get the surrogate to the required plutonium oxidation temperature, $>100^{\circ} \mathrm{C}$.

- If more than $333 \mathrm{~mL}$ of water are required per Rocky Flats sample, a drying step will be needed to insure that the six samples per barrel do not exceed the WIPPWAC limit of two liters of free water ${ }^{2}$.

- Desorption of excess water averaged $3 \mathrm{~g} /$ minute. This suggests that longer processing times will be necessary than initially purposed at Rocky Flats. This in turn would lead to potential secondary waste water problems. 


\section{Plutonium Oxidation}

- The average oxidation rate for plutonium metal was nearly linear over 6 hours.

- Fifty percent oxidation occurred in 6 hours and complete oxidation might occur in 12 hours.

- Submersing the plutonium in water inhibited the oxidation.

- Based on the rates of gas generation, residual plutonium metal in the postoxidized sample may be slightly passivated compared to the starting metal, as concluded from the lessened reactivity in sulfamic acid.

- The post-oxidation $\mathrm{pH}$ was between 6.0 and 6.5, little or no gas generation occurred when the oxidized samples were submerged in water for 1 hour, and the DTA analyses of the oxidized samples exhibited no exotherms. These results indicate the process results in a product that will meet the Rocky Flats stabilization criteria.

- Residual $\mathrm{CCl}_{4}$ from incomplete desorption enhanced the water oxidation through the production of $\mathrm{HCl}$. However, $\mathrm{HCl}$ causes reactor corrosion and could drop the $\mathrm{pH}$ of the product out of WIPP-WAC compliance 2 .

\section{Application of LANL Results to RFETS}

The purpose of this section is to recommend the Parr ${ }^{\circledR}$ reactor configuration that should be used by RFETS personnel for the stabilization of organic contaminated combustible residues based on the information gathered during experimentation. Table 6 summarizes the suggested operating parameters. 
Table 6. RFETS Operating Parameters for Stabilizing Combustible Residues.

\begin{tabular}{lll} 
Process & Parameter & Value \\
\hline Batch Preparation & Sample Batch size & 500 grams combustible \\
Desorption & Air Flow Rate & $75 \mathrm{~L} / \mathrm{min}$. \\
& Air Temperature & $110^{\circ} \mathrm{C}$ \\
Desorption Completion & $\begin{array}{l}\text { Temperature } \\
\text { (center thermocouple) }\end{array}$ & $90^{\circ} \mathrm{C}$ \\
Plutonium Oxidation & $\begin{array}{l}\text { Water Feed Batch Size } \\
\text { Water Preheat Temperature }\end{array}$ & $500 \mathrm{ml}$ \\
& $\begin{array}{l}\text { Oxidation Temperature } \\
100^{\circ} \mathrm{C}\end{array}$ & $100^{\circ} \mathrm{C}-120^{\circ} \mathrm{C}$ \\
& $\begin{array}{l}\text { Oxidation Processing Time } \\
6 \mathrm{hours}\end{array}$ & $50^{\circ} \mathrm{C}$ \\
\hline
\end{tabular}

System Configuration: Details of the system configuration are illustrated in figures 1 and 2. The Design of the system varies slightly compared to the original RFETS design. Design modifications are as follows:

- The water injection tube should allow the liquid to contact the side of the reactor when injected. This will flash the water to vapor.

- The process logic controller (PLC) system must be outside of the glove box environment. Frequent failure of the PLC was attributed to corrosion from process steam.

- The basket should not be constructed with the stainless steel mesh as originally designed as corrosion of the welded edges caused the mesh to fray. The basket should be constructed of a stainless steel rod frame that forms a frame for the nylon hop sack.

Batch Size and Batch Preparation: The batch size should be limited to 500 grams of surrogate as additional material would need to be compacted in order to fit into the reactor basket. Compacting the material would decrease the mass and heat transfer rates during desorption and oxidation. The use of the nylon hop sack is advised as the sack increases the ease of material handling and decreases combustible material spread outside the reactor basket. Oxidation water should be prepared by adding 500 $\mathrm{ml}$ to the water supply vessel and beginning the preheat process. The water should be preheated to $100^{\circ} \mathrm{C}$ prior to reactor injection during oxidation.

Desorption of Volatile Organic Material: After the reactor is sealed and all inlet and outlet valves closed, it should be inductively preheated for one hour. The air inlet 
and off-gas outlet should next be opened and the system sparged with $110^{\circ} \mathrm{C}$ air at 75 liters/minute until the system center thermocouple (the thermocouple in center of the combustible material) reaches $90^{\circ} \mathrm{C}$.

Plutonium Oxidation: The oxidation should begin by pulling a vacuum on the reactor then closing all valves. Next, the drain should be opened to the (preheated) water supply and the water transferred into the reactor vessel. When the system center thermocouple (thermocouple in center of combustible material) reaches $100^{\circ} \mathrm{C}$, this temperature (between $100^{\circ} \mathrm{C}$ and $120^{\circ} \mathrm{C}$ ) should be held for 6 hours. Finally, the reactor should be allowed to cool to approximately $50^{\circ} \mathrm{C}$ and the vessel should be vented before breaking the collar seal.

\section{ACKNOWLEDGMENTS}

The authors wish to thank Kent $D$. Abney for his consultation and guidance on the use of the glovebox and facilities he manages in the Alpha Facility at TA-48, Los Alamos National Laboratory. We also thank David V. Martinez, Los Alamos, for the $\mathrm{CCl}_{4}$ headspace analyses, Jay S. Samuels and Kevin J. Kuhn, Los Alamos, for the DTA analyses, and Dr. Kenneth Ashley, a visiting scientist from Texas A\&MCommerce, who offered many helpful suggestions during the course of this project and never hesitated to offer assistance when asked. 


\section{REFERENCES}

1. "Criteria for Interim Safe Storage (ISSC) of Plutonium-Bearing Solid Materials. "

2. "Waste Acceptance Criteria for the Waste Isolation Pilot Plant", DOE/WIPP-069, Rev. 5, April 1996, pp. 3-24.

3. Code of Federal Regulations, 40CFR261.22 and 49CFR173.187.

4. Schroeder, N.C. and Attrep, M., Jr., "Rocky Flats Wet Combustibles Residue Treatment, Report 1: Wet Combustible-Cerium Studies," LA-UR-962337.

5. Williams, S.B., Schroeder, N.C. and Attrep, M., Jr., "Rocky Flats Wet Combustible Residue Treatment, Cerium Metal Oxidation Studies and Status Report," Los Alamos National Laboratory internal report, September 1996.

6. Haschke, J.M., Allen, T.H., and Stakebake, J.L., "Reaction Kinetics of Plutonium with Oxygen, Water, and Air: Moisture Enhancement of the Corrosion Rate," LAUR-96-632.

7. Jenkins, W. J., I. Inorg. Nucl. Chem, 25, 463 (1963). 